\title{
ML418: The first selective, sub-micromolar pore blocker of Kir7.1 potassium channels
}

\author{
Daniel R. Swale ${ }^{1, €}$, Haruto Kurata ${ }^{2,3, €}$, Sujay V. Kharade ${ }^{1}$, Jonathan Sheehan ${ }^{4}$, Rene R. \\ Raphemot $^{1,2}$, Karl R. Voigtritter ${ }^{2,3}$, Eric Figueroa ${ }^{1,2}$, Jens Meiler ${ }^{4}$, Anna L. Blobaum ${ }^{2,3}$, \\ Craig W. Lindsley ${ }^{2,3}$, Corey R. Hopkins ${ }^{\star}, 2,3$, and Jerod S. Denton ${ }^{*}, 1,2$ \\ ${ }^{1}$ Department of Anesthesiology, Vanderbilt University Medical Center, Nashville, TN 37232 \\ ${ }^{2}$ Department of Pharmacology, Vanderbilt University Medical Center, Nashville, TN 37232 \\ ${ }^{3}$ Vanderbilt Center for Neuroscience Drug Discovery and the Vanderbilt Specialized Chemistry \\ Center for Accelerated Probe Development, Vanderbilt University Medical Center, Nashville, TN \\ 37232 \\ ${ }^{4}$ Department of Chemistry, Vanderbilt University, Nashville, TN 37232
}

\begin{abstract}
The inward rectifier potassium (Kir) channel Kir7.1 (KCNJ13) has recently emerged as a key regulator of melanocortin signaling in the brain, electrolyte homeostasis in the eye, and uterine muscle contractility during pregnancy. The pharmacological tools available for exploring the physiology and therapeutic potential of Kir7.1 have been limited to relatively weak and nonselective small-molecule inhibitors. Here, we report the discovery in a fluorescence-based highthroughput screen of a novel Kir7.1 channel inhibitor, VU714. Site-directed mutagenesis of porelining amino acid residues identified Glutamate 149 and Alanine 150 as essential determinants of VU714 activity. Lead optimization with medicinal chemistry generated ML418, which exhibits sub-micromolar activity $\left(\mathrm{IC}_{50}=310 \mathrm{nM}\right)$ and superior selectivity over other Kir channels (at least 17-fold selective over Kir1.1, Kir2.1, Kir2.2, Kir2.3, Kir3.1/3.2, and Kir4.1) except for Kir6.2/ SUR1 (equally potent). Evaluation in the EuroFins Lead Profiling panel of 64 GPCRs, ionchannels and transporters for off-target activity of ML418 revealed a relatively clean ancillary pharmacology. While ML418 exhibited low $\mathrm{CL}_{\mathrm{HEP}}$ in human microsomes which could be modulated with lipophilicity adjustments, it showed high $\mathrm{CL}_{\mathrm{HEP}}$ in rat microsomes regardless of lipophilicity. A subsequent in vivo PK study of ML418 by intraperitoneal (IP) administration (30 $\mathrm{mg} / \mathrm{kg}$ dosage $)$ revealed a suitable PK profile $\left(\mathrm{C}_{\max }=0.20 \mu \mathrm{M}\right.$ and $\mathrm{T}_{\max }=3$ hours $)$ and favorable CNS distribution (mouse brain:plasma $\mathrm{K}_{\mathrm{p}}$ of 10.9 to support in vivo studies for in vivo studies.
\end{abstract}

\footnotetext{
*Corresponding Authors Jerod S. Denton, Ph.D., T4208 Medical Center North, $116121^{\text {st }}$ Avenue South, Nashville, TN 37232 , jerod.s.denton@vanderbilt.edu, T: 615-343-7385. "Corey R. Hopkins, Ph.D., Cool Springs Life Science Center, 393 Nichol Mill Lane, Franklin, TN 37067, corey.r.hopkins@ vanderbilt.edu, T: 615-936-6892.

$€_{\text {Authors contributed equally }}$

Author Contributions

Conceived and designed the experiments: D.R.S., H.K., K.S.V, J.S., R.R.R, E.F., J.M., A.L.B., C.W.L., C.R.H., J.S.D. Performed data analysis: D.R.S., H.K., K.S.V., R.R.R., K.R.V., E.F., J.S., J.M., A.L.B., C.W.L., C.R.H., Contributed reagents/materials/analysis tools: D.R.S., H.K., J.S., J.M., C.W.L., Wrote manuscript: D.R.S., H.K., J.S., J.M., A.L.B., C.W.L., C.R.H., J.S.D.
} 
ML418, which represents the current state-of-the-art in Kir7.1 inhibitors, should be useful for exploring the physiology of Kir7.1 in vitro and in vivo.

\section{Keywords}

KCNJ13; thallium flux; electrophysiology; comparative modeling; melanocortin signaling; myometrium

\section{INTRODUCTION}

Inward rectifier potassium (Kir) channels play fundamental roles in diverse organ systems, and could in some cases represent unexploited drug targets for neurological, cardiovascular, endocrine, and muscle disorders ${ }^{1,2}$. Kir7.1, which is encoded by KCNJ13, one of sixteen genes comprising the Kir channel family, is expressed in the eye, brain, uterus, kidney, gut, and thyroid gland ${ }^{3-9}$. The genetic loss of Kir7.1 function in retinal pigmented epithelial cells of the eye leads to derangements in subretinal electrolyte homeostasis and cell degeneration underlying leber congenital amaurosis and snowflake vitreoretinopathy ${ }^{10-13}$. Using a panel of mostly non-specific inhibitors with differential activities against Kir channels, GhamariLangroudi and colleagues recently identified Kir7.1-like currents in neurons of the paraventricular nucleus (PVN) that are functionally coupled to the melanocortin-4 receptor $(\mathrm{MC} 4 \mathrm{R})^{14}$. Agonist binding to MC4R inhibits Kir7.1 activity, depolarizes the membrane potential, and increases neuronal firing, whereas competitive antagonist binding increases Kir7.1 activity and dampens neuronal excitability. This model suggests that Kir7.1 coupling to MC4R plays a key role in the central regulation of food intake and energy homeostasis by the $\mathrm{PVN}^{14}$. Kir7.1 expression in uterine muscles increases dramatically during pregnancy, thereby hyperpolarizing the membrane potential, inhibiting calcium signaling, and inducing uterine quiescence during fetal development ${ }^{15}$. Inhibiting Kir7.1 expression with microRNAs or inhibiting channel function with small-molecule inhibitors (i.e. VU590 ${ }^{16}$, MRT00200769 ${ }^{17}$ ) induces long-lasting uterine muscle contractions, lending support to the idea that Kir7.1 represents a novel drug target for augmentation of labor and treating postpartum hemorrhage ${ }^{17}$.

The current pharmacological 'toolkit' for exploring the physiology and therapeutic potential of Kir7.1 is inadequate, prompting us to perform a high-throughput screen (HTS) and lead optimization campaign in order to identify more potent and selective inhibitors. Here, we report the development and in vitro characterization of ML418, a new state-of-the-art inhibitor of Kir7.1.

\section{RESULTS AND DISCUSSION}

\section{Kir7.1-M125R Assay Development}

HTS was performed using a fluorescence-based assay that reports the inward movement of the potassium $\left(\mathrm{K}^{+}\right)$congener thallium $\left(\mathrm{Tl}^{+}\right)$through $\mathrm{Kir} 7.1$ channels expressed in the plasma membrane of T-REx-HEK293 cells. The higher conductance Kir7.1-M125R mutant was used as a surrogate to circumvent the weak $\mathrm{Tl}^{+}$flux observed for wild type (WT) Kir7.1 (see 
ref. ${ }^{18}$ ). As shown in Fig. 1, the assay reports robust Kir7.1-M125R-dependent $\mathrm{Tl}^{+}$flux after induction with tetracycline (Fig. 1A), is DMSO tolerant up to $0.6 \% \mathrm{v} / \mathrm{v}$ (Fig. 1B; screening DMSO concentration $=0.1 \%$ DMSO v/v), and is sufficiently reproducible for HTS (Fig. 1C; mean \pm SEM Z' $=0.67 \pm 0.03 ; n=3$ plates on 3 separate days).

\section{Discovery and Characterization of VU714}

From a pilot screen of 5,230 compounds in the Vanderbilt Institute of Chemical Biology (VICB) library, 11 putative Kir7.1-M125R inhibitors, comprising 5 distinct scaffolds, and with differing levels of selectivity over other Kir channels, were identified (data not shown). VU714 (Fig. 2A) was the most potent and selective inhibitor from the screen, and was therefore re-synthesized and confirmed from powder to be an authentic Kir7.1-M125R inhibitor. VU714 inhibited Kir7.1-M125R-mediated $\mathrm{Tl}^{+}$flux in a dose-dependent manner with an $\mathrm{IC}_{50}$ of $5.6 \mu \mathrm{M}$ (95\% Confidence Interval [CI]: $\left.1.9 \mu \mathrm{M}-17.5 \mu \mathrm{M}\right)$ (Fig 2B-C). In "gold-standard" whole-cell voltage clamp experiments, the rate of Kir7.1-M125R inhibition by VU714 was concentration dependent (Fig. 2D), $10 \mu \mathrm{M}$ VU714 fully inhibited outward and inward Kir7.1-M125R-mediated current (Fig. 2E), and the $\mathrm{IC}_{50}$ was $1.5 \mu \mathrm{M}$ (CI: $1.3 \mu \mathrm{M}$ $-1.7 \mu \mathrm{M})($ Fig. $2 \mathrm{~F})$. The 3.7-fold shift in $\mathrm{IC}_{50}$ determined with patch clamp electrophysiology, as compared with $\mathrm{Tl}^{+}$flux, is consistent with previous observations of other Kir channel inhibitors ${ }^{18-20}$. Quantitative $\mathrm{Tl}^{+}$flux assays were utilized to evaluate the selectivity of VU714 for Kir7.1 over Kir1.1, Kir2.1, Kir2.2, Kir2.3, Kir3.1/3.2, Kir4.1, and Kir6.2/SUR1, as reported previously 16, 21, 22. The concentration-response curves (CRCs) shown in Fig. 3A revealed that VU714 is only moderately selective, and inhibits other Kir channels with a rank order potency of Kir7.1 $\left(\mathrm{IC}_{50}=5.6 \mu \mathrm{M}\right)>\operatorname{Kir} 4.1\left(\mathrm{IC}_{50}=13 \mu \mathrm{M}\right)>$ $\operatorname{Kir} 1.1\left(\mathrm{IC}_{50}=16 \mu \mathrm{M}\right)>\operatorname{Kir} 6.2 / \mathrm{SUR} 1\left(\mathrm{IC}_{50}=30 \mu \mathrm{M}\right)>\operatorname{Kir} 2.1, \operatorname{Kir} 2.2, \operatorname{Kir} 2.3, \operatorname{Kir} 3.1 / 3.2$ $\left(\mathrm{IC}_{50}>30 \mu \mathrm{M}\right)$. Kir2.2,Kir2.3, and Kir3.1/3.2 CRCs have been excluded from Fig. 3A for clarity.

\section{VU714 Requires Pore-lining E149 and A150 Residues for Activity}

Kir channels are tetrameric proteins consisting of 8 membrane-spanning domains, an ionconduction pore, and cytoplasmic domain. Most small-molecule inhibitors studied to date appear to block the conduction pathway by interacting with amino acid residues lining the transmembrane pore (reviewed in ${ }^{1}$ ). We therefore performed scanning mutagenesis and voltage-clamp electrophysiology to test if VU714 interacts with pore-lining amino acids in Kir7.1. Residues that are predicted from homology modeling (Fig. 4A) to face the pore were mutated to the corresponding residues in Kir2.1 and Kir1.1, which are only weakly inhibited by (Kir1.1) or insensitive (Kir2.1) to VU714 (Fig. 3A). Mutations were first introduced into WT Kir7.1, and if they impaired channel activity, were retested in the M125R background due to its more robust functional expression and ability to rescue the activity of some mutants. For clarity, only non-functional mutants in the M125R background are indicated in Fig. 4B; however, these mutations were first tested in the WT background and found to be non-functional. The M125R mutation does not alter VU714 sensitivity (Fig. 4C).

Mutations L146V, I160M, and A161S had no effect on Kir7.1 inhibition by $3 \mu \mathrm{M}$ VU714, whereas the T153C/WT mutation significantly $(\mathrm{P}<0.05)$ increased channel inhibition. Mutation of E149 to the corresponding Asparagine residue in Kir1.1 (E149N) abolished 
Kir7.1 activity in both WT and M125R backgrounds. However, the more conservative mutation, E149Q/M125R, led to a partial, albeit significant $(\mathrm{P}<0.05)$, loss of sensitivity to VU714. The negative charge at position 149 appears to be important for VU714 activity since mutating E149 to Aspartate (E149D) had no effect on block. Mutation of the adjacent residue A150 to Serine (A150S) led to a partial loss of inhibition. As shown in Fig. 4C, the E149Q and A150S mutations significantly $(\mathrm{P}<0.0001)$ shifted the $\mathrm{IC}_{50}$ for VU714 from 2 $\mu \mathrm{M}$ in the WT or M125R mutants to $\sim 18 \mu \mathrm{M}$ and $\sim 7 \mu \mathrm{M}$, respectively. Mutation of both residues simultaneously led to an additive loss of VU714 sensitivity (Fig. 4B).

Molecular modeling was used to visualize how VU714 might interact with Kir7.1 to induce channel block. Interactive ligand placement near E149 and A150, combined with energy minimization, revealed the best theoretical configuration of VU714 in the Kir7.1 channel pore (Fig. 4D-E). The limited volume of the pore in the putative binding region results in obstruction of the channel by VU714, just below the selectivity filter. This model suggests a straightforward steric mechanism for the observed conduction block by VU714. It is notable that this general region of pore is also involved in block of Kir1.1 by VU591 ${ }^{23}$, Kir2.1 by ML133 ${ }^{24}$, and Kir4.1 by fluoxetine ${ }^{25}$ (reviewed in ref. ${ }^{1}$ ). Pentamidine ${ }^{26}$ and chloroquine ${ }^{27}$ require residues in the cytoplasmic pore for block; however, it is unlike that these residues participate in VU714 inhibition of Kir7.1 since the double mutation E149Q and A150S virtually eliminated block of the channel (Fig. 4B).

\section{VU714 Structure-Activity Relationships}

Medicinal chemistry was employed in an effort to identify VU714 analogs with improved potency and selectivity for Kir7.1. Our first priority was to reduce the high lipophilicity of VU714 ( $\log P=5.83$ ), which may be a liability for off-target selectivity, metabolism and toxicity. The initial library to explore SAR (Structure-Activity Relationship) in the righthand portion of VU714 identified several equipotent moieties, including a simple methyl compound $\left(1, \mathrm{IC}_{50}=4.8 \mu \mathrm{M}, \operatorname{clog} \mathrm{P}=4.41\right)$ without the benzyl moiety (Table 1$)$. Subsequent libraries with a hydrophilic handle indicated that changing the piperidine ring system to a piperazine was not productive (amide, sulfonamide, urea and carbamate, $\mathbf{2}-\mathbf{6}$ ), including the direct benzyl analog which resulted in a 4.5-fold loss of potency compared to VU714 (5, $\left.\mathrm{IC}_{50}=22.0 \mu \mathrm{M}\right)$. However, attaching a hydrophilic handle (-NHR') at the 4-position of the piperidine ring system endowed less lipophilic compounds with equal potency to the HTS hit compound, namely the amide compound $\left(7, \mathrm{IC}_{50}=8.3 \mu \mathrm{M}, \operatorname{cog} \mathrm{P}=3.43\right)$ and the carbamate $\left(11, \mathrm{IC}_{50}=1.7 \mu \mathrm{M}, \operatorname{cog} \mathrm{P}=3.65\right)$ which were generally more potent than the corresponding $N$-alkylated derivatives (12 - 16) (Table 1). Based on these results, we next evaluated a number of carbamate analogs in order to explore the SAR around this moiety (Table 2). While the simple methyl carbamate (17, inactive) and ethyl carbamate $\left(\mathbf{1 8}, \mathrm{IC}_{50}=\right.$ $9.8 \mu \mathrm{M})$ analogs were less active, all of the branched alkyl carbamates $(\mathbf{1 9}-\mathbf{2 2})$ were equipotent with the HTS hit compound. Among them, the isopropyl $\left(\mathbf{1 9}, \mathrm{IC}_{50}=1.3 \mu \mathrm{M}\right.$, $\operatorname{cog} \mathrm{P}=3.25)$ and the tert-butyl carbamate $\left(\mathbf{1 1}, \mathrm{IC}_{50}=1.7 \mu \mathrm{M}\right.$, $\left.\operatorname{cog} \mathrm{P}=3.65\right)$ were the most active compounds. The benzyl compound (23), ring contracted compounds ( 24 and 25$)$ and the spirocyclic compounds (26 and 27) were also tolerated, but less active than the HTS hit VU714. The next library was focused on right-hand 4-aminopiperidine amide analogs. The most active amides were aryl analogs in nature $(\mathbf{2 8}-\mathbf{4 0}, \mathbf{4 3})$ with the 3-chlorophenyl (32, 
$\left.\mathrm{IC}_{50}=3.1 \mu \mathrm{M}, \operatorname{cog} \mathrm{P}=4.34\right)$ being the most potent in this class. Branched alkyl amides (41 -42) were also evaluated, but they were less active than the parent compound (Table 2).

Next, we explored SAR around a left-hand quinoline moiety keeping the 4-methyl piperidine in the right-hand portion constant. Unfortunately, structural modifications of this portion of the molecule were not well tolerated, even minor changes such as changing the chlorine to fluorine and bromine atoms were less active. The only modification tolerated in our SAR exploration was an introduction of a methyl group at the 4-position of the quinoline ring (Fig. S1).

The SAR data (Fig. S1) is in qualitative agreement with the docking model that illustrates a plausible binding mode (Fig. 4E). Specifically, position 2 of the quinoline ring faces towards the protein backbone. There is no space for additional bulk. This is in contrast to positions 3 and 4 of the quinoline ring where methyl substitution is tolerated. The Nitrogen atom of the quinoline points to a polar pocket that could provide space for an additional, hydrogenbound water molecule. A Carbon atom could not engage in these favorable interactions. The chloride and hydroxyl substituents are in tight, polar pockets. No larger substituents will fit into these pockets. A quantitative analysis of the agreement is beyond the predictive power of the homology model used for the docking simulation.

\section{Discovery and Characterization of ML418}

Having identified several VU714 analogs with lower lipophilicity and similar potencies in $\mathrm{Tl}^{+}$flux assays, we next evaluated their activity toward Kir7.1 using voltage clamp electrophysiology and selectivity among Kir1.1, Kir2.1, Kir2.2, Kir2.3, Kir3.1/3.2, Kir4.1 and Kir6.2/SUR1 in $\mathrm{Tl}^{+}$flux assays. The methyl piperidine analog (1) was similar in activity and selectivity to VU714 (Table 3). However, the carbamate (11 and 19) and amide (32) analogs exhibited superior inhibitory activity and selectivity. The isopropyl carbamate analog is the most potent in Kir7.1 activity (19= ML418) in our library and is at least 23fold selective against the Kir channels tested, with the exception of Kir6.2/SUR1 (Fig. 3B; Table 3). ML418 inhibits Kir7.1 dose-dependently (Fig. 3C) with an $\mathrm{IC}_{50}$ in patch clamp electrophysiology experiments of $310 \mathrm{nM}$ (Fig. 3D; Table 3). While the tert-butyl carbamate (11) showed similar potency and selectivity to ML418, the amide analog (32) exhibited modest activity and greater than 10-fold selectivity over the Kir channels tested (Table 3). Although compounds $\mathbf{4 4}$ and $\mathbf{4 5}$ also show selectivity preference over Kir6.2/SUR1, and should be considered for use as an in vitro tool compound, the totality of the properties favors ML418 as the first selective Kir7.1 inhibitor.

In a Lead Profiling Screen (Eurofins) of 64 potential off-targets, ML418 showed a relatively clean ancillary pharmacology having significant interactions (i.e. $>50 \%$ radioligand displacement) with the L-type calcium channel, voltage-gated sodium channel, Dopamine D2S and D4.2 receptors, Sigma $\sigma 1$ receptor, and Norepinephrine receptor (Table S1).

SUPPORTING INFORMATION

SAR, chemical synthesis of all analogs, in vitro pharmacology procedures, in vitro PK methods, in vivo PK methods. 


\section{DMPK Evaluation for Selected Analogs}

We evaluated selected analogs in our in vitro DMPK panel of assays, an assessment of intrinsic clearance $\left(\mathrm{CL}_{\mathrm{INT}}\right)$ and predicted hepatic clearance $\left(\mathrm{CL}_{\mathrm{HEP}}\right)$ in hepatic microsomes and protein binding in plasma (PPB) in multiple species. Interestingly, while the lipophilic HTS hit compound VU714 (cLogP $=5.83$ ) was shown to have high intrinsic clearance $\left(\mathrm{CL}_{\mathrm{HEP}}(\right.$ human $)=16.7 \mathrm{~mL} / \mathrm{min} / \mathrm{kg}$ and $\left.\mathrm{CL}_{\mathrm{HEP}}(\mathrm{rat})=64.1 \mathrm{~mL} / \mathrm{min} / \mathrm{kg}\right)$ and low unbound fraction in plasma $\left(\% \mathrm{~F}_{u}(\right.$ mouse $)=0.7, \% \mathrm{~F}_{u}($ rat $)=1.8$ and $\% \mathrm{~F}_{u}($ human $\left.)=0.5\right)$ across species, more potent analogs than VU714 (32,11 and 19= ML418) exhibited lower intrinsic clearance in human hepatic microsomes $\left(\mathrm{CL}_{\mathrm{HEP}}\right.$ (human) $=10.7,7.9$ and $3.6 \mathrm{~mL} / \mathrm{min} / \mathrm{kg}$, respectively) and higher unbound fraction in mouse and rat plasma $\left(\% \mathrm{~F}_{u}\right.$ (mouse $)=2.0,5.6$ and 11.4 and $\% \mathrm{~F}_{u}($ rat $)=2.5,3.6$ and 8.8 , respectively) as the cLogPs are reduced. While intrinsic clearance in rat hepatic microsomes of ML418 are slightly reduced $\left(\mathrm{CL}_{\mathrm{HEP}}\right.$ (rat) $=57.9 \mathrm{~mL} / \mathrm{min} / \mathrm{kg}$ ) compared to VU714, subsequent PK study of ML418 by $30 \mathrm{mg} / \mathrm{kg}$ dosage of intraperitoneal administration revealed its characteristic PK profile (Fig. 5: $\mathrm{C}_{\max }=$ $0.20 \mu \mathrm{M}$ and $\mathrm{T}_{\max }=3$ hours). It may be attributed to enterohepatic recirculation caused by phenol moiety. In a parallel CNS distribution study in mice, ML418 demonstrated excellent CNS penetration with a mouse brain:plasma ratio $\left(\mathrm{K}_{\mathrm{p}}\right)$ of 10.9 (average of four mice, brain (323.9 ng/g):plasma $(29.5 \mathrm{ng} / \mathrm{mL})$ ). Thus, ML418 possesses a DMPK profile suitable for both in vitro and in vivo studies aimed at modulating both peripheral and central Kir7.1 potassium channels.

\section{CONCLUSIONS}

ML418 is the fifth small-molecule inhibitor of Kir7.1 reported to date and currently represents the state-of-the-art for the field (Table 5). The first Kir7.1 inhibitor, VU590, was identified in a HTS of approximately 225,000 compounds for inhibitors of Kir1.1 $\left(\mathrm{IC}_{50}=\right.$ $0.24 \mu \mathrm{M})$ and subsequently found to have weak off-target activity toward Kir7.1 $\left(\mathrm{IC}_{50} \sim 8\right.$ $\mu \mathrm{M})^{16}$. Evaluation of eight VU590 analogs revealed a flat SAR against Kir7.1 ${ }^{17}$. Another compound, VU573 was identified in the same Kir1.1 HTS, but found to have superior activity toward Kir7.1 $\left(\mathrm{IC}_{50}=4.9 \mu \mathrm{M}\right)$ over Kir1.1 $\left(\mathrm{IC}_{50}=19 \mu \mathrm{M}\right)$ in $\mathrm{Tl}^{+}$flux assays. VU573 also inhibits Kir2.3 and Kir3 channels with single-micromolar potency ${ }^{18}$. Lead optimization efforts failed to generate more potent or selective inhibitors of Kir7.1, but did generate 'inactive' analogs that can be useful for determining the specificity of VU573 in pharmacology experiments targeting Kir7.1 (e.g. see ref. ${ }^{14}$ ). ML133 was identified in a HTS of more than 300,000 compounds for modulators of Kir2.1 ( $\mathrm{IC}_{50}=0.3 \mu \mathrm{M}$ at pH 8.0; approximately equal activity toward Kir2.2, Kir2.3, and Kir2.6) and found to possess weak Kir7.1 activity $\left(\mathrm{IC}_{50}=33 \mu \mathrm{M}\right)^{24}$. MRT00200769 was discovered in an electrophysiologybased screen of 7,087 compounds for Kir7.1 inhibitors, but, despite being one of the most potent Kir7.1 inhibitors identified, was found to exhibit preferential activity toward cardiac hERG K ${ }^{+}$channels $\left(\mathrm{IC}_{50}=0.3 \mu \mathrm{M}\right)$ over Kir7.1 $\left(\mathrm{IC}_{50}=1.3 \mu \mathrm{M}\right)$. MRT00200769 also suffers from flat $\mathrm{SAR}^{17}$. In the present study, a HTS of 5,230 compounds from the VICB library led to the discovery of the novel pore blocker VU714, which was optimized with medicinal chemistry to generate ML418. The salient features of ML418 include: 1) Kir7.1 $\mathrm{IC}_{50}=0.3$ $\mu \mathrm{M} ; 2$ ) at least 23-fold selectivity for Kir7.1 over Kir1.1, Kir2.1, Kir2.2, Kir2.3, Kir4.1 except for Kir6.2/SUR1; 3) clean ancillary pharmacology against 58 GPCRs, ion channels, 
and transporters, including hERG; 4) PK profile in rat $\left(\mathrm{C}_{\max }=0.20 \mu \mathrm{M}\right.$ and $\mathrm{T}_{\max }=3$ hours at $30 \mathrm{mg} / \mathrm{kg}$ i.p. dosing) and highly CNS penetrant (mouse brain:plasma $\mathrm{K}_{\mathrm{p}}$ of 10.9). Further investigations of ML418 in order to probe the detailed physiological functions of Kir7.1 will be reported in due course.

\section{METHODS}

\section{Molecular biology}

The open reading frame (ORF) of human Kir7.1 was sub-cloned into pcDNA5/TO (Life Technologies) to enable tetracycline-regulated expression (see below). Mutations were introduced into the Kir7.1 ORF using a QuickChange II mutagenesis kit (Agilent Technologies) and sequenced to verify incorporation of the intended mutation.

\section{Tetracycline-inducible stable cell lines}

Stably transfected T-REx-HEK-293 cell lines expressing the following Kir channels were generated and maintained in culture as described previously: Kir1.1 ${ }^{28}$, Kir2.1 ${ }^{22}, \mathrm{Kir} 4.1^{21}$, Kir6.2/SUR1 ${ }^{22}$, Kir7.1-M125R ${ }^{18}$. Kir channel expression was induced by culturing cells overnight in media containing $1 \mu \mathrm{g} / \mathrm{ml}$ tetracycline.

\section{High-throughput screening (HTS)}

HTS for Kir7.1-M125R modulators was performed using a $\mathrm{Tl}^{+}$-flux reporter assay essentially as described previously $16,20,21$. The Kir7.1-M125R mutation increases the channel unitary conductance and enables robust $\mathrm{Tl}^{+}$flux measurement that cannot be achieved with the WT channel ${ }^{18}$. T-REx-HEK-293-Kir7.1-M125R cells (20,000/well) were plated in clear-bottomed, black-walled, 384-well plates, and cultured overnight in Delbecco's Modified Eagle's Medium (DMEM) containing 10\% dialyzed FBS and $1 \mu \mathrm{g} / \mathrm{ml}$ tetracycline to induce Kir7.1-M125R expression. The following day, the cells were incubated with dye-loading assay buffer (Hank's Balanced Salt Solution, $20 \mathrm{mM}$ HEPES, pH 7.3) containing $0.01 \%$ (w/v) Pluronic F-127 (Life Technologies) and $1.2 \mu \mathrm{M}$ ThallosAM (TEFlabs, Austin, TX) $\mathrm{Tl}^{+}$reporter dye. The dye-loading solution was replaced after $1 \mathrm{hr}$ with $20 \mu \mathrm{L} /$ well assay buffer. Test compounds from the VICB Library were dispensed into 384-well plates using an Echo555 liquid handler (Labcyte, Sunnyvale, CA) and diluted to a $2 \mathrm{X}$ concentration. Cell plates were transferred to a Hamamatsu Functional Drug Screening System 6000 (FDSS6000; Hamamatsu, Tokyo, Japan) where $20 \mu \mathrm{L} /$ well test compounds were dispensed into wells to a nominal concentration of $10 \mu \mathrm{M}$. After a 20-min incubation period, baseline fluorescence (excitation $470 \pm 20 \mathrm{~nm}$, emission $540 \pm 30 \mathrm{~nm}$ ) was recorded at $1 \mathrm{~Hz}$ for $10 \mathrm{sec}$ before addition of thallium stimulus buffer containing (in $\mathrm{mM}$ ): $125 \mathrm{NaHCO}_{3}, 1.8 \mathrm{CaSO}_{4}, 1 \mathrm{MgSO}_{4}, 5$ glucose, and $1.8 \mathrm{Tl}_{2} \mathrm{SO}$. Fluorescence data were collected for an additional $4 \mathrm{~min}$ at $1 \mathrm{~Hz}$. Data were analyzed essentially as described previously 28,29 using a combination of Microsoft Excel (Microsoft Corporation, Redmond, WA) with XLfit add-in (IDBS, Guildford, Surrey, UK) and GraphPad Prism ${ }^{\mathrm{TM}}$ (GraphPad Software, San Diego, CA, USA). Raw data were opened in Microsoft Excel and each data point in a given trace was divided by the first data point from that trace followed by subtraction of data points from control traces that were generated in the presence of vehicle controls. The slope of the fluorescence increase beginning $5 \mathrm{sec}$ after $\mathrm{Tl}^{+}$addition and 
ending $20 \mathrm{sec}$ after $\mathrm{Tl}^{+}$addition was calculated. The data were then plotted in Prism software to generate CRCs. Potencies were calculated from fits to CRC data using a nonlinear regression analysis.

\section{Transient transfections and whole-cell patch clamp electrophysiology}

Transfections and whole-cell patch clamp experiments were performed essentially as described previously ${ }^{22}$. Briefly, HEK-293T cells were transfected with plasmids encoding WT or mutant Kir7.1 and EGFP (transfection marker) using Lipofectamine LTX (Life Technologies). The next day, the cells were dissociated with trypsin, plated on poly-Llysine-coated round glass coverslips, and allowed to recover for at least $1 \mathrm{hr}$ before beginning experiments. Coverslips were transferred to a small-volume recording chamber on the stage of an inverted fluorescence microscope and superfused with a control bath solution containing (in $\mathrm{mM}$ ), $135 \mathrm{NaCl}, 5 \mathrm{KCl}, 2 \mathrm{CaCl}_{2}, 1 \mathrm{MgCl}_{2}, 5$ glucose, 10 HEPES, pH 7.4. Electrodes were pulled with a Flaming-Brown P-1000 micropipette puller and had resistances between 2-3 M $\Omega$ when filled with the following solution (in $\mathrm{mM}$ ): $135 \mathrm{mM} \mathrm{KCl}$, $2 \mathrm{MgCl}_{2}, 1$ EGTA, $10 \mathrm{HEPES}, \mathrm{pH}$ 7.3. The cells were voltage clamped at a holding potential of $-75 \mathrm{mV}$ and then stepped to $-120 \mathrm{mV}$ for $500 \mathrm{msec}$ before ramping to $120 \mathrm{mV}$ at a rate of $2.4 \mathrm{mv} / \mathrm{msec}$. The cell potential was returned to $-75 \mathrm{msec}$ for $5 \mathrm{sec}$ before initiating the step-ramp protocol again. Dose-response experiments were performed by superfusing cells with increasing doses of Kir7.1 inhibitor (e.g. ML418) followed by $4 \mathrm{mM} \mathrm{BaCl}_{2}$ to fully block Kir7.1. Cells exhibiting less than $90 \%$ block by $\mathrm{BaCl}_{2}$ were excluded from analysis. $\mathrm{IC}_{50}$ values were determined by fitting the Hill equation to $\mathrm{CRCs}$ using variable-slope, unconstrained, nonlinear regression analyses performed with GraphPad Prism (GraphPad Software, San Diego, CA, USA). All experiments yielded acceptable Hill slope (>0.8) and $\mathrm{r}^{2}$ (0.99) values. IC50 values are expressed as mean of $\mathrm{n}=5$ values. Mean $\mathrm{IC}_{50}$ values and $95 \%$ confidence limits were determined with GraphPad InStatTM (GraphPad Software, San Diego, CA, USA). The mean $\mathrm{IC}_{50}$ values were statistically analyzed using a one-way ANOVA measure with Dunnets multiple comparison test with significance being represented by $\mathrm{P}<0.05$. Statistical analyses were performed using InStatTM (GraphPad Software, San Diego, CA, USA).

\section{Comparative homology modeling and in silico docking}

A comparative model of Kir7.1 was generated based on the 3.11 Angstrom resolution crystal structure Kir2.2 (PDB ID 3JYC) ${ }^{30}$. The sequence identity between Kir7.1 and Kir2.2 is $33.5 \%$ among the 343 residues aligned in each subunit of the tetramer. MODELLER version 9.9 [REF 2] was used to construct the model. The inhibitor VU0488714 was docked into the model of Kir7.1 using the Molecular Operating Environment (MOE) software package ${ }^{31}$. Docking was performed by allowing flexibility of the ligand molecule and also the side chains of the protein model. A representative docking pose was selected from among the 29 lowest-energy results by choosing the best-scoring pose that features multiple interactions between the inhibitor and the experimentally-determined residues glutamate 149 and alanine 150 . 


\section{Chemical synthesis}

General. All NMR spectra were recorded on a $400 \mathrm{MHz}$ AMX Bruker NMR

spectrometer. ${ }^{1} \mathrm{H}$ and ${ }^{13} \mathrm{C}$ chemical shifts are reported in $\delta$ values in ppm downfield with the deuterated solvent as the internal standard. Data are reported as follows: chemical shift, multiplicity ( $\mathrm{s}=$ singlet, $\mathrm{d}=$ doublet, $\mathrm{t}=$ triplet, $\mathrm{q}=$ quartet, $\mathrm{b}=$ broad, $\mathrm{m}=$ multiplet), integration, coupling constant $(\mathrm{Hz})$. Low resolution mass spectra were obtained on an Agilent 6120 or 6150 with ESI source. Method A: MS parameters were as follows: fragmentor: 70, capillary voltage: $3000 \mathrm{~V}$, nebulizer pressure: $30 \mathrm{psig}$, drying gas flow: $13 \mathrm{~L} /$ min, drying gas temperature: $350{ }^{\circ} \mathrm{C}$. Samples were introduced via an Agilent 1290 UHPLC comprised of a G4220A binary pump, G4226A ALS, G1316C TCC, and G4212A DAD with ULD flow cell. UV absorption was generally observed at $215 \mathrm{~nm}$ and $254 \mathrm{~nm}$ with a $4 \mathrm{~nm}$ bandwidth. Column: Waters Acquity BEH C18, $1.0 \times 50 \mathrm{~mm}, 1.7 \mathrm{um}$. Gradient conditions: $5 \%$ to $95 \% \mathrm{CH}_{3} \mathrm{CN}$ in $\mathrm{H}_{2} \mathrm{O}\left(0.1 \%\right.$ TFA) over $1.4 \mathrm{~min}$, hold at $95 \% \mathrm{CH}_{3} \mathrm{CN}$ for $0.1 \mathrm{~min}, 0.5$ $\mathrm{mL} / \mathrm{min}, 55^{\circ} \mathrm{C}$. Method B: MS parameters were as follows: fragmentor: 100, capillary voltage: $3000 \mathrm{~V}$, nebulizer pressure: $40 \mathrm{psig}$, drying gas flow: $11 \mathrm{~L} / \mathrm{min}$, drying gas temperature: $350{ }^{\circ} \mathrm{C}$. Samples were introduced via an Agilent 1200 HPLC comprised of a degasser, G1312A binary pump, G1367B HP-ALS, G1316A TCC, G1315D DAD, and a Varian 380 ELSD (if applicable). UV absorption was generally observed at $215 \mathrm{~nm}$ and 254 $\mathrm{nm}$ with a $4 \mathrm{~nm}$ bandwidth. Column: Thermo Accucore C18, $2.1 \times 30 \mathrm{~mm}, 2.6 \mathrm{um}$. Gradient conditions: $7 \%$ to $95 \% \mathrm{CH}_{3} \mathrm{CN}$ in $\mathrm{H}_{2} \mathrm{O}\left(0.1 \%\right.$ TFA) over $1.6 \mathrm{~min}$, hold at $95 \% \mathrm{CH}_{3} \mathrm{CN}$ for $0.35 \mathrm{~min}, 1.5 \mathrm{~mL} / \mathrm{min}, 45^{\circ} \mathrm{C}$. High resolution mass spectra were obtained on an Agilent 6540 UHD Q-TOF with ESI source. MS parameters were as follows: fragmentor: 150, capillary voltage: $3500 \mathrm{~V}$, nebulizer pressure: $60 \mathrm{psig}$, drying gas flow: $13 \mathrm{~L} / \mathrm{min}$, drying gas temperature: $275^{\circ} \mathrm{C}$. Samples were introduced via an Agilent 1200 UHPLC comprised of a G4220A binary pump, G4226A ALS, G1316C TCC, and G4212A DAD with ULD flow cell. UV absorption was observed at $215 \mathrm{~nm}$ and $254 \mathrm{~nm}$ with a $4 \mathrm{~nm}$ bandwidth. Column: Agilent Zorbax Extend C18, $1.8 \mu \mathrm{m}, 2.1 \times 50 \mathrm{~mm}$. Gradient conditions: $5 \%$ to $95 \% \mathrm{CH}_{3} \mathrm{CN}$ in $\mathrm{H}_{2} \mathrm{O}(0.1 \%$ formic acid $)$ over $1 \mathrm{~min}$, hold at $95 \% \mathrm{CH}_{3} \mathrm{CN}$ for $0.1 \mathrm{~min}, 0.5 \mathrm{~mL} / \mathrm{min}, 40{ }^{\circ} \mathrm{C}$. For compounds that were purified on a Gilson preparative reversed-phase HPLC, the system comprised of a 333 aqueous pump with solvent-selection valve, 334 organic pump, GX-271 or GX-281 liquid hander, two column switching valves, and a 155 UV detector. UV wavelength for fraction collection was user-defined, with absorbance at $254 \mathrm{~nm}$ always monitored. Method: Phenomenex Axia-packed Luna C18, $30 \times 50 \mathrm{~mm}, 5 \mu \mathrm{m}$ column. Mobile phase: $\mathrm{CH}_{3} \mathrm{CN}$ in $\mathrm{H}_{2} \mathrm{O}$ ( $0.1 \%$ TFA). Gradient conditions: 0.75 min equilibration, followed by user defined gradient (starting organic percentage, ending organic percentage, duration), hold at $95 \% \mathrm{CH}_{3} \mathrm{CN}$ in $\mathrm{H}_{2} \mathrm{O}\left(0.1 \%\right.$ TFA) for $1 \mathrm{~min}, 50 \mathrm{~mL} / \mathrm{min}, 23{ }^{\circ} \mathrm{C}$. Solvents for extraction, washing and chromatography were HPLC grade. All reagents were purchased from Aldrich Chemical Co. and were used without purification.

\section{Synthetic scheme and characterization of ML418}

Synthetic scheme of ML418 is shown in Figure S2 as an example of general synthetic scheme. Experimental procedure for ML418 is described below. Specific synthetic schemes for each compound are also shown in supplemental information (Figures S3-6). 


\section{5-Chloro-8-hydroxyquinoline-7-carbaldehyde (49A)}

To a solution of 5-chloroquinolin-8-ol 48A $(8.08 \mathrm{~g}, 45.0 \mathrm{mmol})$ in TFA $(75 \mathrm{~mL})$ was added hexamethylenetetramine $(12.62 \mathrm{~g}, 90.0 \mathrm{mmol})$ at ambient temperature. After a resulting reddish solution was refluxed at $120-130^{\circ} \mathrm{C}$ for 5 hours, $1 \mathrm{~mol} / \mathrm{L} \mathrm{HCl}$-aq $(200 \mathrm{~mL})$ was added to the reaction mixture at $0^{\circ} \mathrm{C}$ which was stirred at ambient temperature for $20 \mathrm{~min}$. To the reaction mixture was added ethyl acetate $(75 \mathrm{~mL})$ and $5 \mathrm{~mol} / \mathrm{L} \mathrm{NaOH}-a q(140 \mathrm{~mL})$ at $0^{\circ} \mathrm{C}$. The resulting precipitates were collected by filtration and washed with water to give a crude product $(6.59 \mathrm{~g})$ which was triturated with mixed solvent of $\mathrm{EtOH}(25 \mathrm{~mL})$ and $\mathrm{Et}_{2} \mathrm{O}$ $(20 \mathrm{~mL})$ to yield 5-chloro-8-hydroxyquinoline-7-carbaldehyde 49A (3.480 g, 37\% yield) as a beige powder.

\section{tert-Butyl (1-((5-chloro-8-hydroxyquinolin-7-yl)methyl)piperidin-4-yl)carbamate (11)}

To a suspension of 49A (818 mg, $3.94 \mathrm{mmol})$ in DCM (25 mL) was added 4-bocaminopiperidine $(1.58 \mathrm{~g}, 7.89 \mathrm{mmol})$ at ambient temperature. After a resulting greenish solution was stirred at ambient temperature for 1 hour, sodium triacetoxyborohydride (1.25 $\mathrm{g}, 5.91 \mathrm{mmol}$ ) was added to the reaction mixture which was stirred at ambient temperature for 18 hours. The reaction mixture was poured into $\mathrm{NaHCO}_{3}-\mathrm{aq}(150 \mathrm{~mL})$ and it was extracted with DCM ( $\left.1^{\text {st }}: 125 \mathrm{~mL}, 2^{\text {nd. }}: 50 \mathrm{~mL}\right)$. Combined organic extracts were washed with $\left(\mathrm{NaHCO}_{3}-\mathrm{aq}+\right.$ water + brine $)$ and dried over $\mathrm{MgSO}_{4}$. The filtrate was evaporated under reduced pressure to give crude product $(2.28 \mathrm{~g}$ ) which was purified on silica gel chromatography $(\mathrm{DCM} / \mathrm{MeOH})$ after combined with another crude product $(1.41 \mathrm{~g})$ by same reaction conditions from 49A $(451 \mathrm{mg}, 2.17 \mathrm{mmol})$ to yield tert-butyl (1-((5-chloro-8hydroxyquinolin-7-yl)methyl)piperidin-4-yl)carbamate 11 (2.05 g, 86\% yield) as a pale yellow powder.

\section{7-((4-Aminopiperidin-1-yl)methyl)-5-chloroquinolin-8-ol trihydrochloride (51)}

To a suspension of $\mathbf{1 1}(1.034 \mathrm{~g}, 2.64 \mathrm{mmol})$ in 1,4-dioxane $(10 \mathrm{~mL})$ was added $\mathrm{HCl} / 1,4$ dioxane $(4 \mathrm{~mol} / \mathrm{L}, 20 \mathrm{~mL})$ at ambient temperature. After a reaction mixture was stirred for 24 hours, the precipitate was collected by filtration to yield 7-((4-aminopiperidin-1yl)methyl)-5-chloroquinolin-8-ol trihydrochloride 51 (1.034 g, 98\% yield) as a yellow powder.

\section{iso-Propyl (1-((5-chloro-8-hydroxyquinolin-7-yl)methyl)piperidin-4-yl)carbamate (19 = ML418)}

To a solution of $\mathbf{5 1}(1.015 \mathrm{~g}, 2.53 \mathrm{mmol})$ and DIPEA $(1.76 \mathrm{~mL}, 10.1 \mathrm{mmol})$ in DCM $(25$ $\mathrm{mL}$ ) was added a solution of iso-propyl chloroformate in toluene $(2 \mathrm{~mol} / \mathrm{L}, 1.30 \mathrm{~mL}, 2.66$ $\mathrm{mmol}$ ) at $0^{\circ} \mathrm{C}$. After a resulting greenish solution was stirred at ambient temperature for 1 hour, it was poured into ice/ $\mathrm{NaHCO}_{3}-a q$, which was extracted with DCM (x 2). Combined organic extracts were dried over $\mathrm{MgSO}_{4}$ and the filtrate was evaporated under reduced pressure. The residue was purified by Gilson HPLC separation system using $(0.1 \%$ TFA in water)/CH3CN as an eluent to give crude product (c.a. $1.1 \mathrm{~g}$ ) which was recrystallized from $\mathrm{Et}_{2} \mathrm{O}$ to yield desired product ( $633 \mathrm{mg} 51 \%$ yield) as a TFA salt. To a solution of TFA salt of the desired product $(1,236 \mathrm{~g}, 2.51 \mathrm{mmol})$ in DCM $(37 \mathrm{~mL})$ was added saturated $\mathrm{NaHCO}_{3}$-aq $(12.5 \mathrm{~mL})$ at ambient temperature. Organic phase was separated and aqueous phase was 
extracted with DCM (x 2). Combined organic phase was dried over $\mathrm{MgSO}_{4}$. The filtrate was evaporated under reduced pressure to yield iso-propyl (1-((5-chloro-8-hydroxyquinolin-7yl)methyl)piperidin-4-yl)carbamate 19 (ML418) (915 mg, 96\% yield) as a pale yellow powder. ${ }^{1} \mathrm{H}$ NMR (400.1 MHz, DMSO- $d_{6}$ ): $8.93(\mathrm{dd}, \mathrm{J}=4.2,1.3 \mathrm{~Hz}, 1 \mathrm{H}), 8.47$ (dd, J = 8.5, $1.3 \mathrm{~Hz}, 1 \mathrm{H}), 7.69(\mathrm{dd}, \mathrm{J}=8.5,4.2 \mathrm{~Hz}, 1 \mathrm{H}), 7.61(\mathrm{~s}, 1 \mathrm{H}), 7.02(\mathrm{~d}, \mathrm{~J}=7.7 \mathrm{~Hz}, 1 \mathrm{H}), 4.73$ (sept, $\mathrm{J}=6.2 \mathrm{~Hz}, 1 \mathrm{H}), 3.51-3.16(\mathrm{br}, 1 \mathrm{H}), 2.85-2.82(\mathrm{~m}, 2 \mathrm{H}), 2.15-2.10(\mathrm{~m}, 2 \mathrm{H}), 1.75-1.72(\mathrm{~m}$, $2 \mathrm{H}), 1.46-1.39(\mathrm{~m}, 2 \mathrm{H}), 1.16(\mathrm{~d}, \mathrm{~J}=6.2 \mathrm{~Hz}, 6 \mathrm{H}) .{ }^{13} \mathrm{C}$ NMR (100.6 MHz, DMSO- $\left.d_{6}\right)$ : 155.61, 151.63, 149.47, 139.31, 132.80, 128.72, 125.33, 123.09, 121.32, 118.58, 66.86, 56.62, 52.36, 47.98, 32.29, 22.58. LCMS: $\mathrm{R}_{\mathrm{T}}=0.773 \mathrm{~min}, \mathrm{~m} / \mathrm{z}=378[\mathrm{M}+\mathrm{H}]^{+}$. HRMS calc'd for: $\mathrm{C}_{19} \mathrm{H}_{24} \mathrm{ClN}_{3} \mathrm{O}_{3}\left[\mathrm{M}^{+}\right]$, 377.1506; found 377.1507.

\section{Acknowledgments}

Funding

This work was funded in part by the Vanderbilt Institute of Clinical and Translational Research pilot grant (D.R.S, J.S.D.), DK082884 (J.S.D.), and MLPCN (C.R.H, C.W.L.).

\section{REFERENCES}

1. Swale DR, Kharade SV, Denton JS. Cardiac and renal inward rectifier potassium channel pharmacology: emerging tools for integrative physiology and therapeutics. Curr Opin Pharmacol. 2014; 15:7-15. [PubMed: 24721648]

2. Denton JS, Pao AC, Maduke M. Invited Review - Novel Diuretic Targets. Am J Physiol Renal Physiol. 2013; 305(7):F931-F942. [PubMed: 23863472]

3. Ookata K, Tojo A, Suzuki Y, Nakamura N, Kimura K, Wilcox CS, Hirose S. Localization of inward rectifier potassium channel Kir7.1 in the basolateral membrane of distal nephron and collecting duct. J Am Soc Nephrol. 2000; 11(11):1987-1994. [PubMed: 11053473]

4. Nakamura N, Suzuki Y, Sakuta H, Ookata K, Kawahara K, Hirose S. Inwardly rectifying $\mathrm{K}^{+}$ channel Kir7.1 is highly expressed in thyroid follicular cells, intestinal epithelial cells and choroid plexus epithelial cells: implication for a functional coupling with $\mathrm{Na}^{+} \mathrm{K}^{+}$-ATPase. Biochem J. 1999; 342(Pt 2):329-336. [PubMed: 10455019]

5. Krapivinsky G, Medina I, Eng L, Krapivinsky L, Yang Y, Clapham DE. A novel inward rectifier $\mathrm{K}^{+}$ channel with unique pore properties. Neuron. 1998; 20(5):995-1005. [PubMed: 9620703]

6. Yasuda K, Shimura M, Nakazawa T, Sato H, Tomita H, Sugano E, Tamai M. Expression and functional properties of unique inward rectifier $\mathrm{K}^{+}$channel Kir7.1 in the porcine iris and retinal pigment epithelium. Curr Eye Res. 2003; 27(5):279-287. [PubMed: 14562164]

7. Fujita A, Horio Y, Higashi K, Mouri T, Hata F, Takeguchi N, Kurachi Y. Specific localization of an inwardly rectifying $\mathrm{K}(+)$ channel, Kir4.1, at the apical membrane of rat gastric parietal cells; its possible involvement in $\mathrm{K}^{+}$recycling for the $\mathrm{H}^{+}-\mathrm{K}^{+}$-pump. J Physiol. 2002; 540(Pt 1):85-92. [PubMed: 11927671]

8. Kusaka S, Inanobe A, Fujita A, Makino Y, Tanemoto M, Matsushita K, Tano Y, Kurachi Y. Functional Kir7.1 channels localized at the root of apical processes in rat retinal pigment epithelium. J Physiol. 2001; 531(Pt 1):27-36. [PubMed: 11179389]

9. Derst C, Hirsch JR, Preisig-Muller R, Wischmeyer E, Karschin A, Doring F, Thomzig A, Veh RW, Schlatter E, Kummer W, Daut J. Cellular localization of the potassium channel Kir7.1 in guinea pig and human kidney. Kidney Int. 2001; 59(6):2197-2205. [PubMed: 11380822]

10. Pattnaik BR, Shahi PK, Marino MJ, Liu X, York N, Brar S, Chiang J, Pillers AM, Traboulsi EI. A Novel KCNJ13 Nonsense Mutation and Loss of Kir7.1 Channel Function Causes Leber Congenital Amaurosis (LCA16). Hum Mutat. 2015

11. Pattnaik BR, Tokarz S, Asuma MP, Schroeder T, Sharma A, Mitchell JC, Edwards AO, Pillers DA. Snowflake vitreoretinal degeneration (SVD) mutation R162W provides new insights into Kir7.1 ion channel structure and function. PLoS One. 2013; 8(8):e71744. [PubMed: 23977131] 
12. Sergouniotis PI, Davidson AE, Mackay DS, Li Z, Yang X, Plagnol V, Moore AT, Webster AR. Recessive mutations in $K C N J 13$, encoding an inwardly rectifying potassium channel subunit, cause leber congenital amaurosis. Am J Hum Genet. 2011; 89(1):183-190. [PubMed: 21763485]

13. Hejtmancik JF, Jiao X, Li A, Sergeev YV, Ding X, Sharma AK, Chan CC, Medina I, Edwards AO. Mutations in KCNJ13 cause autosomal-dominant snowflake vitreoretinal degeneration. Am J Hum Genet. 2008; 82(1):174-180. [PubMed: 18179896]

14. Ghamari-Langroudi M, Digby GJ, Sebag JA, Millhauser GL, Palomino R, Matthews R, Gillyard T, Panaro BL, Tough IR, Cox HM, Denton JS, Cone RD. G-protein-independent coupling of MC4R to Kir7.1 in hypothalamic neurons. Nature. 2015; 520(7545):94-98. [PubMed: 25600267]

15. McCloskey C, Rada C, Bailey E, McCavera S, van den Berg HA, Atia J, Rand DA, Shmygol A, Chan YW, Quenby S, Brosens JJ, Vatish M, Zhang J, Denton JS, Taggart MJ, Kettleborough C, Tickle D, Jerman J, Wright P, Dale T, Kanumilli S, Trezise DJ, Thornton S, Brown P, Catalano R, Lin N, England SK, Blanks AM. The inwardly rectifying $\mathrm{K}^{+}$channel Kir7.1 controls uterine excitability throughout pregnancy. EMBO Mol Med. 2014; 6(9):1161-1174. [PubMed: 25056913]

16. Lewis LM, Bhave G, Chauder BA, Banerjee S, Lornsen KA, Redha R, Fallen K, Lindsley CW, Weaver CD, Denton JS. High-throughput screening reveals a small-molecule inhibitor of the renal outer medullary potassium channel and Kir7.1. Mol Pharmacol. 2009; 76(5):1094-1103. [PubMed: 19706730]

17. Wright PD, Kanumilli S, Tickle D, Cartland J, Bouloc N, Dale T, Tresize DJ, McCloskey C, McCavera S, Blanks AM, Kettleborough C, Jerman JC. A High-Throughput Electrophysiology Assay Identifies Inhibitors of the Inwardly Rectifying Potassium Channel Kir7.1. J Biomol Screen. 2015

18. Raphemot R, Lonergan DF, Nguyen TT, Utley T, Lewis LM, Kadakia R, Weaver CD, Gogliotti R, Hopkins C, Lindsley CW, Denton JS. Discovery, characterization, and structure-activity relationships of an inhibitor of inward rectifier potassium (Kir) channels with preference for Kir2.3, Kir3.x, and Kir7.1. Front Pharmacol. 2011; 2:75. [PubMed: 22275899]

19. Raphemot R, Rouhier MF, Hopkins CR, Gogliotti RD, Lovell KM, Hine RM, Ghosalkar D, Longo A, Beyenbach KW, Denton JS, Piermarini PM. Eliciting renal failure in mosquitoes with a smallmolecule inhibitor of inward-rectifying potassium channels. PLoS One. 2013; 8(5):e64905. [PubMed: 23734226]

20. Raphemot R, Rouhier MF, Swale DR, Days E, Weaver CD, Lovell KM, Konkel LC, Engers DW, Bollinger SF, Hopkins C, Piermarini PM, Denton JS. Discovery and Characterization of a Potent and Selective Inhibitor of Aedes aegypti Inward Rectifier Potassium Channels. PLoS One. 2014; 9(11):e110772. [PubMed: 25375326]

21. Raphemot R, Kadakia RJ, Olsen ML, Banerjee S, Days E, Smith SS, Weaver CD, Denton JS. Development and validation of fluorescence-based and automated patch clamp-based functional assays for the inward rectifier potassium channel Kir4.1. Assay Drug Dev Technol. 2013; 11(910):532-543. [PubMed: 24266659]

22. Raphemot R, Swale DR, Dadi PK, Jacobson DA, Cooper P, Wojtovich AP, Banerjee S, Nichols C, Denton JS. Direct Activation of beta-cell $\mathrm{K}_{\text {ATP }}$ Channels with a Novel Xanthine Derivative. Mol Pharmacol. 2014

23. Swale DR, Sheehan JH, Banerjee S, Husni AS, Nguyen TT, Meiler J, Denton JS. Computational and Functional Analyses of a Small-Molecule Binding Site in ROMK. Biophys J. 2015; 108(5): 1094-1103. [PubMed: 25762321]

24. Wang HR, Wu M, Yu H, Long S, Stevens A, Engers DW, Sackin H, Daniels JS, Dawson ES, Hopkins CR, Lindsley CW, Li M, McManus OB. Selective inhibition of the Kir2 family of inward rectifier potassium channels by a small molecule probe: the discovery, SAR, and pharmacological characterization of ML133. ACS Chem Biol. 2011; 6(8):845-856. [PubMed: 21615117]

25. Furutani K, Ohno Y, Inanobe A, Hibino H, Kurachi Y. Mutational and in silico analyses for antidepressant block of astroglial inward-rectifier Kir4.1 channel. Mol Pharmacol. 2009; 75(6): 1287-1295. [PubMed: 19264848]

26. de Boer TP, Nalos L, Stary A, Kok B, Houtman MJ, Antoons G, van Veen TA, Beekman JD, de Groot BL, Opthof T, Rook MB, Vos MA, van der Heyden MA. The anti-protozoal drug pentamidine blocks Kir2.x-mediated inward rectifier current by entering the cytoplasmic pore region of the channel. Br J Pharmacol. 2010; 159(7):1532-1541. [PubMed: 20180941] 
27. Rodriguez-Menchaca AA, Navarro-Polanco RA, Ferrer-Villada T, Rupp J, Sachse FB, TristaniFirouzi M, Sanchez-Chapula JA. The molecular basis of chloroquine block of the inward rectifier Kir2.1 channel. Proc Natl Acad Sci U S A. 2008; 105(4):1364-1368. [PubMed: 18216262]

28. Bhave G, Chauder BA, Liu W, Dawson ES, Kadakia R, Nguyen TT, Lewis LM, Meiler J, Weaver CD, Satlin LM, Lindsley CW, Denton JS. Development of a selective small-molecule inhibitor of Kir1.1, the renal outer medullary potassium channel. Mol Pharmacol. 2011; 79(1):42-50. [PubMed: 20926757]

29. Raphemot R, Weaver CD, Denton JS. High-throughput Screening for Small-molecule Modulators of Inward Rectifier Potassium Channels. J Vis Exp. 2013; (71)

30. Tao X, Avalos JL, Chen J, MacKinnon R. Crystal structure of the eukaryotic strong inward-rectifier $\mathrm{K}^{+}$channel Kir2.2 at 3.1 A resolution. Science. 2009; 326(5960):1668-1674. [PubMed: 20019282]

31. Chemical Computing Group, I. Molecular Operating Environment (MOE). Canada: Montreal, QC; 2015. 


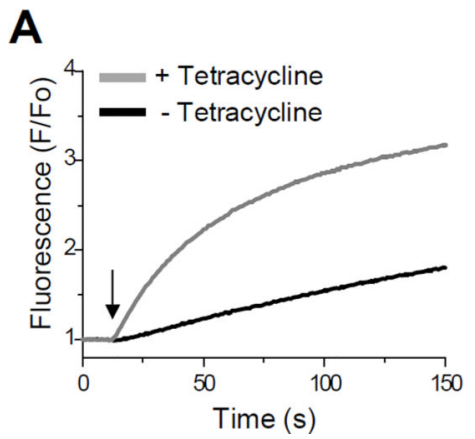

B

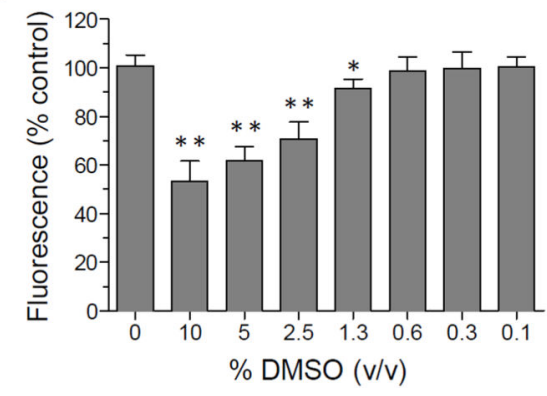

C

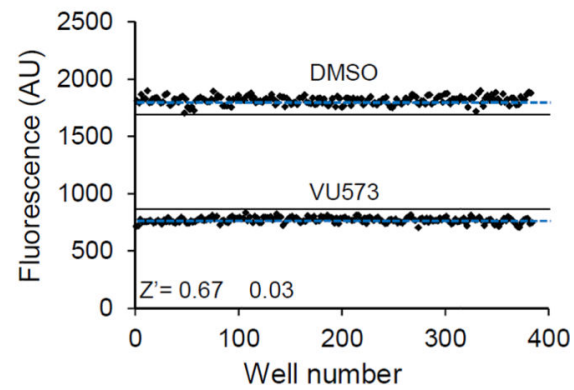

Figure 1. Kir7.1 $\mathrm{Tl}^{+}$flux assay used for HTS

(A) Representative Thallos fluorescence traces recorded from T-REx-HEK-293-Kir7.1M125R cells cultured overnight with (grey line) or without (black line) tetracycline.

Thallium stimulus buffer was added to each well simultaneously as indicated with the arrow.

(B) DMSO tolerance test indicating that DMSO has no effect on Kir7.1-M125R-mediated $\mathrm{Tl}^{+}$flux as concentrations up to $1.3 \%$ (v/v). (C) Determination of assay reproducibility. Alternate wells of a 384-well plate were treated with DMSO (vehicle) or Kir7.1 inhibitor VU573 $(30 \mu \mathrm{M})$ before initiating $\mathrm{Tl}^{+}$flux. Mean fluorescence and 3 S.D. from the mean for each well population are indicated with a blue dashed line and solid black line, respectively. The mean \pm SEM. Z' for 3 plates assayed on 3 separate days was $Z$ ' $=0.67 \pm 0.03$. 
A

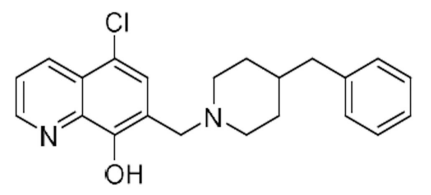

VU714

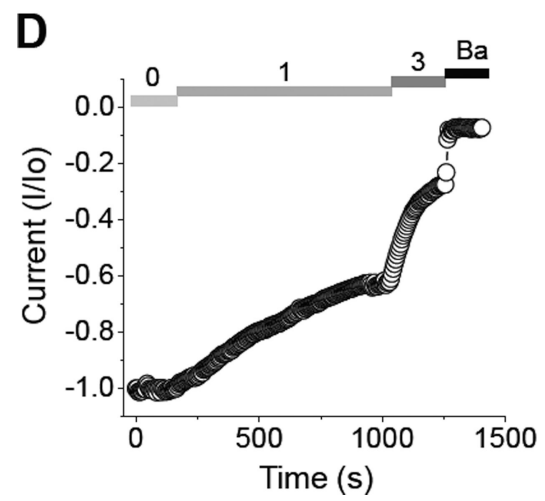

B

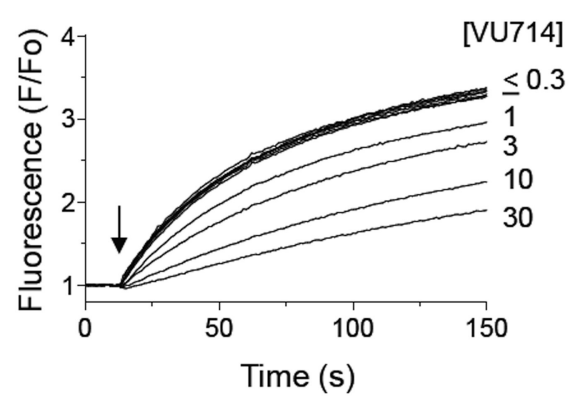

E

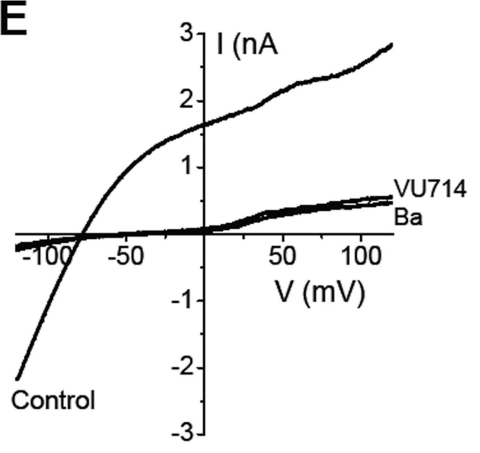

C

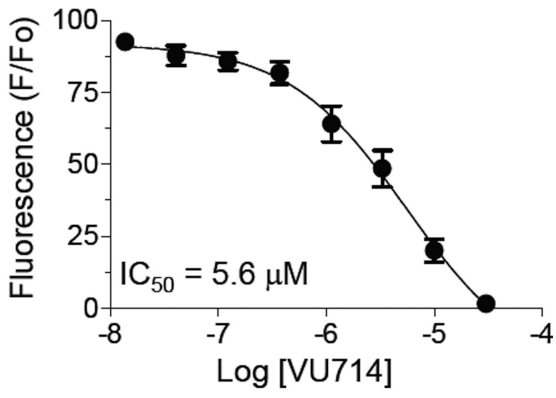

$\mathbf{F}$

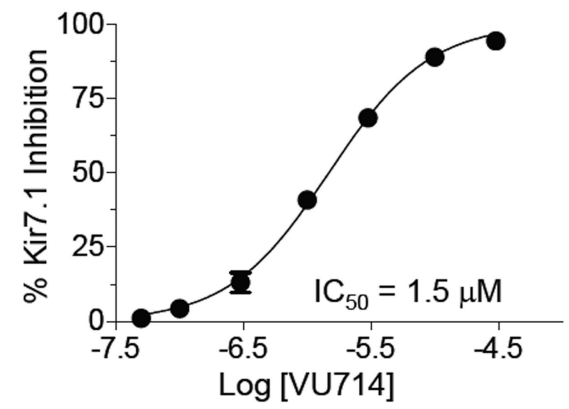

Figure 2. Discovery and characterization of VU714

(A) Chemical structure of VU714. (B) Dose-dependent inhibition of Kir7.1-M125Rdependent $\mathrm{Tl}^{+}$flux by VU714. Cells were pre-treated with the indicated concentrations of VU714 for 10 min before adding $\mathrm{Tl}^{+}$stimulus buffer (arrow). (C) Mean \pm SEM $\%$ control fluorescence recorded in the indicated concentrations of VU714 $(n=4)$. (D) Representative whole-cell patch clamp experiment showing timecourse of VU714-dependent inhibition of Kir7.1 current recorded at $-120 \mathrm{mV}$. VU714 concentrations (in $\mu \mathrm{M}$ ) are indicated at the top. Experiments were terminated by bath application of $2 \mathrm{mM}$ barium (Ba). (E) Current-voltage plot showing inhibition of Kir7.1 by $10 \mu \mathrm{M}$ VU714 or $2 \mathrm{mM} \mathrm{Ba}$. (F) Mean \pm SEM \% Kir7.1 inhibition at $-120 \mathrm{mV}$. $\mathrm{IC}_{50}$ values were derived by fitting CRC data with a 4-parameter logistical function. 
A

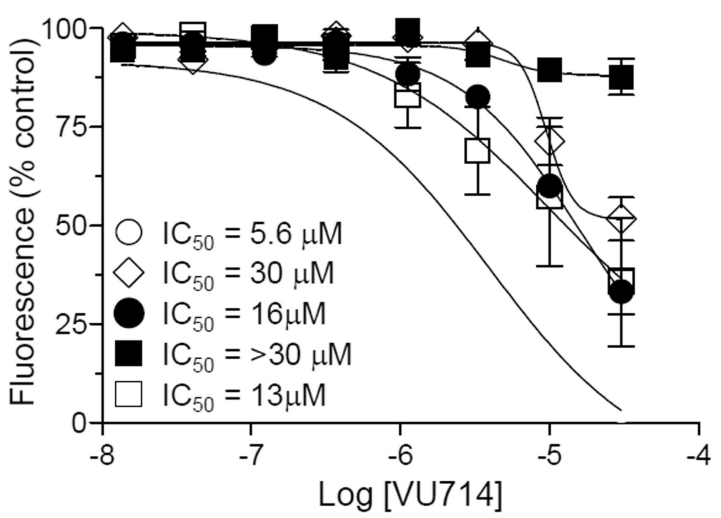

C

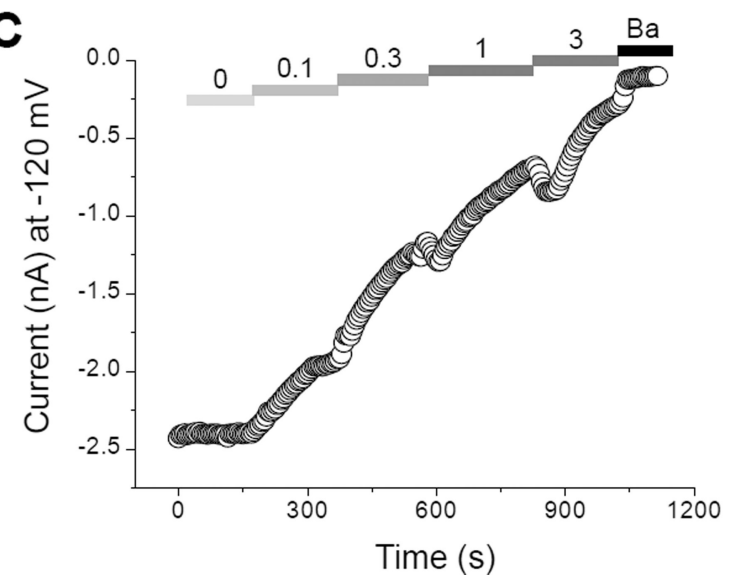

B

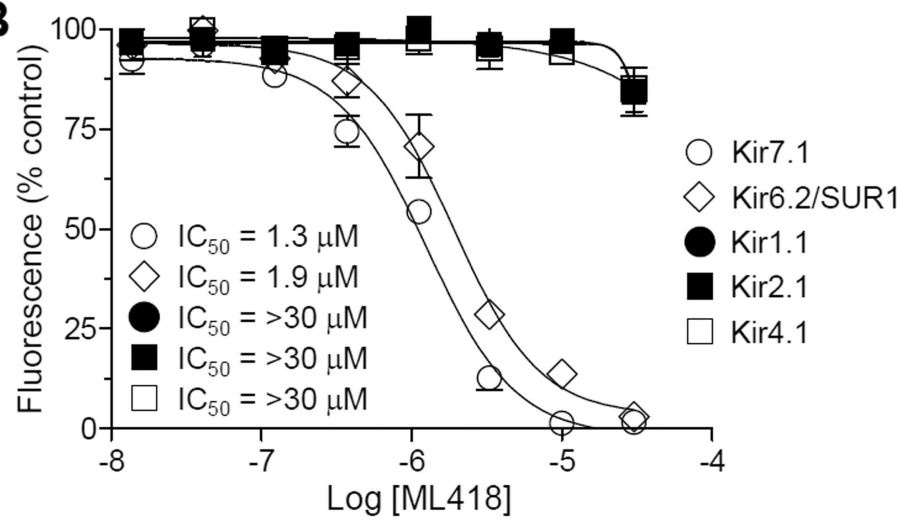

D

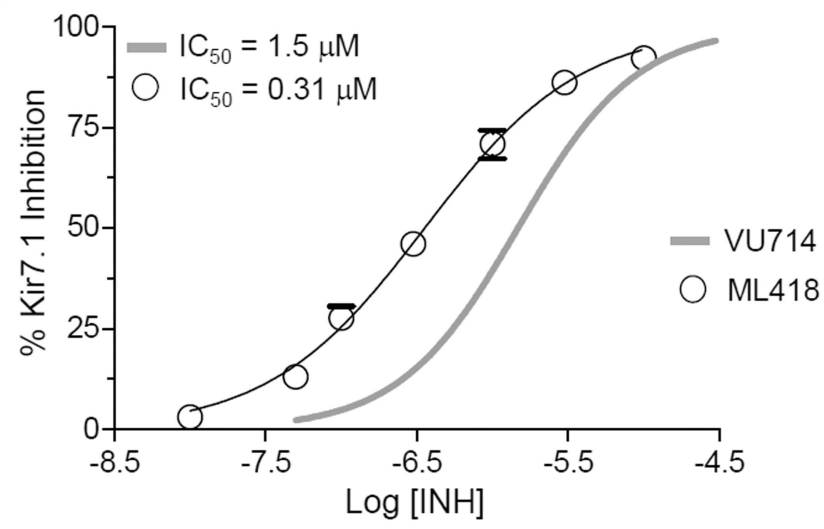

Figure 3. Analysis of VU714 and ML418 selectivity for Kir7.1 over other Kir channels (A) VU714 CRCs constructed for Kir7.1-M125R over Kir6.2/SUR1 (open diamonds), Kir1.1 (closed circles), Kir2.1 (closed squares), Kir4.1 (open squares) in $\mathrm{Tl}^{+}$flux assays. Kir2.2,Kir2.3, Kir3.1/3.2 $\left(\mathrm{IC}_{50} \mathrm{~s}>30 \mu \mathrm{M}\right)$ have been excluded for clarity. Data are means \pm SEM \% control fluorescence ( $\mathrm{n}=4-10$ per concentration). (B) ML418 CRCs constructed for the same channels in $\mathrm{Tl}^{+}$flux assays. (C) Representative whole-cell patch clamp experiment showing dose-dependent inhibition of Kir7.1 current at $-120 \mathrm{mV}$ by the indicated concentration of ML418. The experiment was terminated by bath application of 2 mM Ba. (D) Comparison of CRCs for VU714 (grey line, data from Fig. 2) and ML418 determined in patch clamp electrophysiology experiments. 

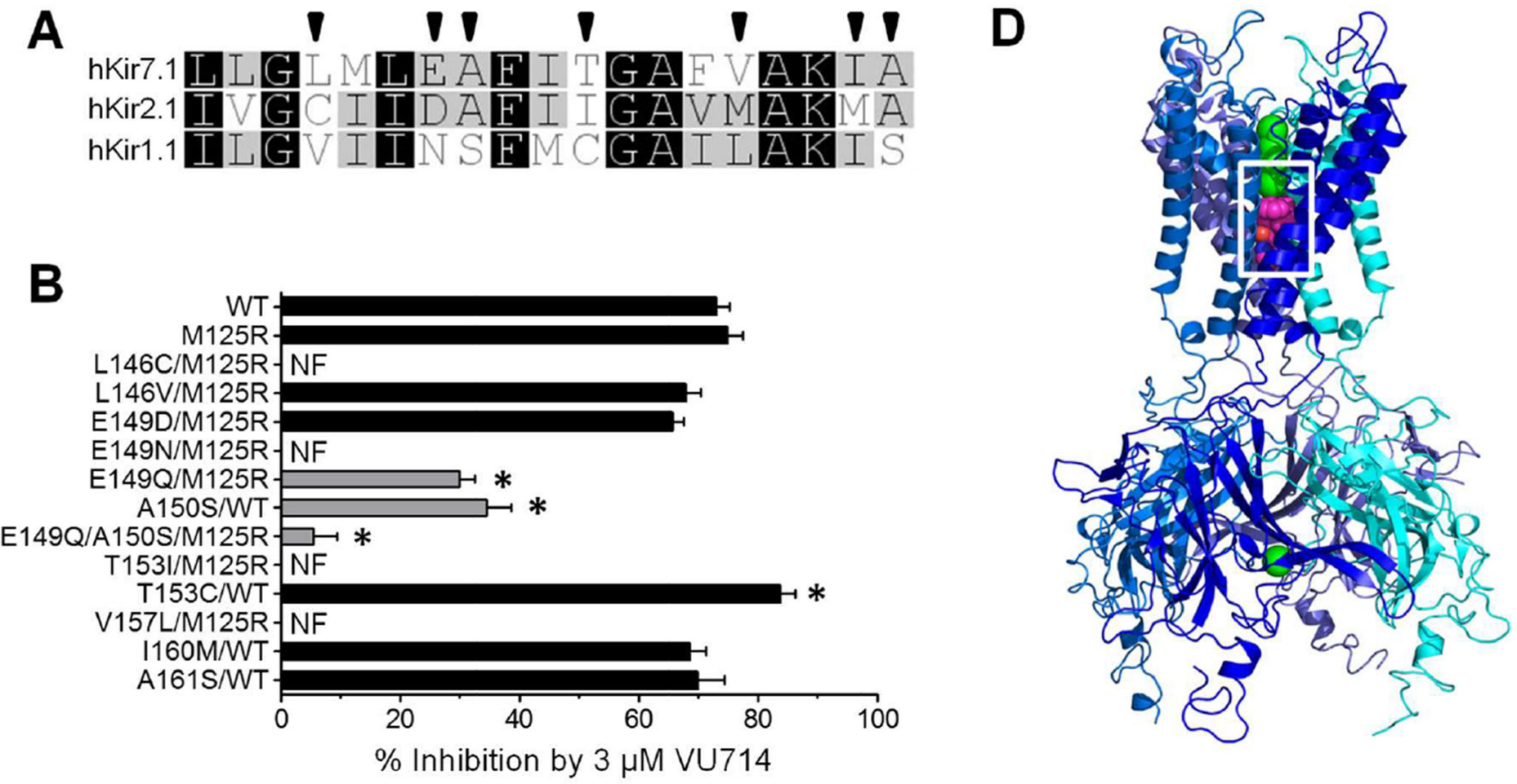

\section{C}

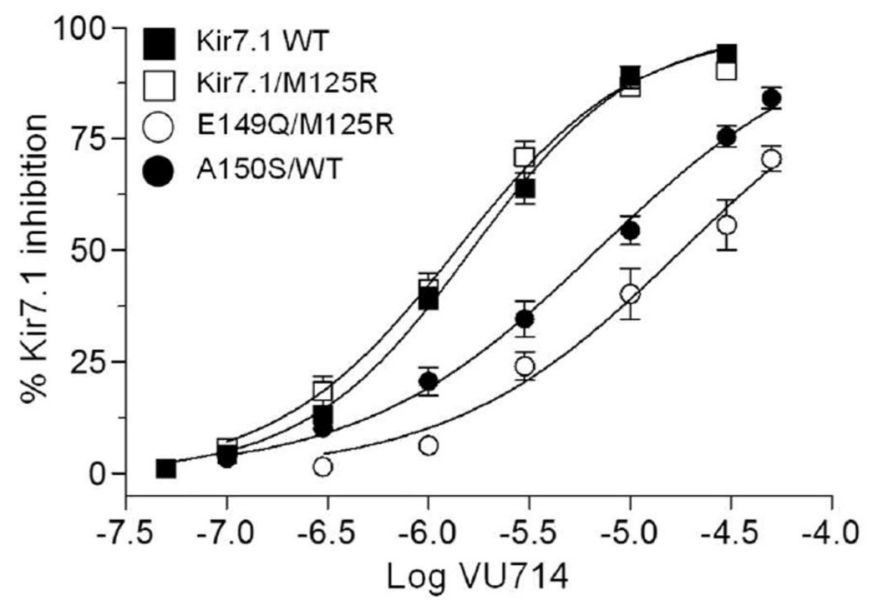

E

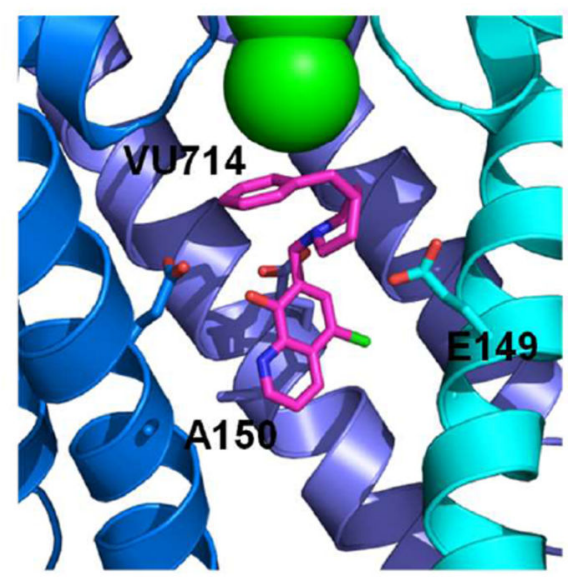

Figure 4. Identification of pore-lining residues in Kir7.1 required for VU714 activity (A) Alignment of pore-lining M2 helices from human Kir7.1, Kir2.1, and Kir1.1, with predicted pore-facing residues indicated with arrowheads. (B) Effects of pore mutations on Kir7.1-WT or Kir7.1-M125R sensitivity to $3 \mu \mathrm{M}$ VU714. Data are mean \pm SEM $\%$ inhibition at $-120 \mathrm{mV}$. $* \mathrm{P}<0.05$ compared to respective control. N.F., not functional. (C) VU714 CRC for Kir7.1-WT (closed squares; $\mathrm{IC}_{50}=1.4 \mu \mathrm{M}$ ), Kir7.1-M125R (open squares; $\mathrm{IC}_{50}=1.6 \mu \mathrm{M}$ ), Kir7.1-M125R-E148Q (open circles; $\mathrm{IC}_{50}=18.1 \mu \mathrm{M}$ ), Kir7.1-WT-A150S (closed circles; $\mathrm{IC}_{50}=6.9 \mu \mathrm{M}$ ). (D) Kir7.1 homology model showing low-energy pose of VU714 near residues E149 and A150. (E) Higher-magnification view (from white box in D) of VU714 near E149 and A150. 


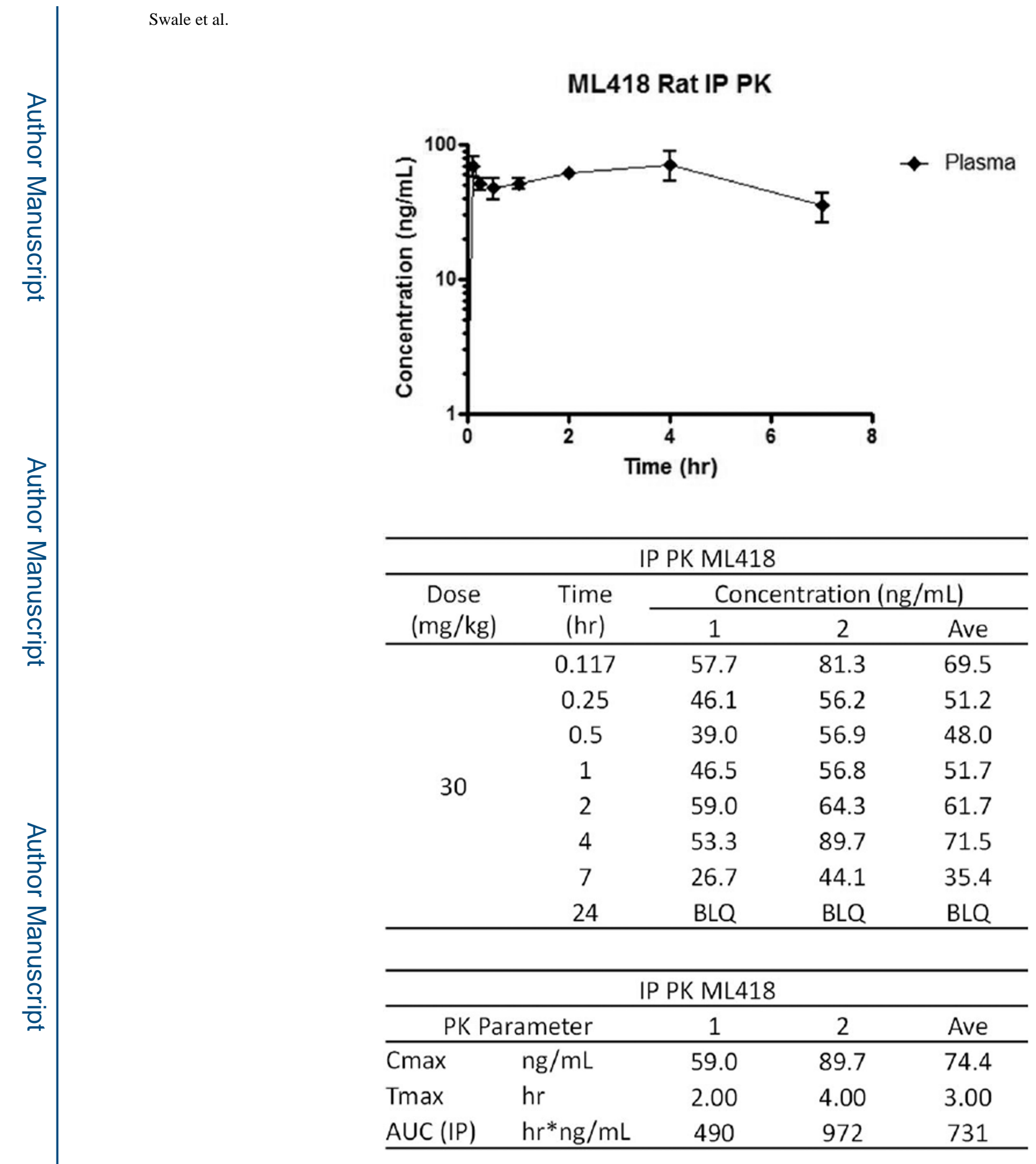

Figure 5. Time course in vivo PK profile of ML418

ML418 was dosed at $30 \mathrm{mg} / \mathrm{kg}$ in $10 \% \mathrm{EtOH}, 40 \%$ PEG 400, 50\% saline vehicle. The dosing solution was administered by intraperitoneal injection and whole blood collections via the carotid artery were performed at $0.117,0.25,0.5,1,2,4,7$, and 24 hours post dose.

ACS Chem Neurosci. Author manuscript; available in PMC 2016 December 01. 


\section{Table 1}

SAR on attaching hydrophilic handles in a right-hand portion

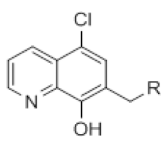

\begin{tabular}{|c|c|c|c|}
\hline Entry & $\mathbf{R}$ & $\mathbf{R}^{\prime}$ & $\begin{array}{c}\text { Kir7.1 IC } \\
\quad(\mu \mathrm{M})^{a}\end{array}$ \\
\hline 1 & & - & 4.8 \\
\hline 2 & & $\mathrm{COPh}$ & Inactive \\
\hline 3 & & $\mathrm{SO}_{2} \mathrm{Ph}$ & Inactive \\
\hline 4 & & CONHPh & Inactive \\
\hline 5 & & $\mathrm{CH}_{2} \mathrm{Ph}$ & 22.6 \\
\hline 6 & & $\mathrm{CO}_{2} \mathrm{Bu}^{t}$ & Inactive \\
\hline 7 & & $\mathrm{COPh}$ & 8.3 \\
\hline 8 & & $\mathrm{SO}_{2} \mathrm{Ph}$ & 14.7 \\
\hline 9 & & CONHPh & 15.8 \\
\hline 10 & & $\mathrm{CH}_{2} \mathrm{Ph}$ & 12.4 \\
\hline 11 & & $\mathrm{CO}_{2} \mathrm{Bu}^{t}$ & 1.7 \\
\hline 12 & & $\mathrm{COPh}$ & Inactive \\
\hline 13 & & $\mathrm{SO}_{2} \mathrm{Ph}$ & 12.2 \\
\hline 14 & & CONHPh & 23.6 \\
\hline 15 & & $\mathrm{CH}_{2} \mathrm{Ph}$ & 7.4 \\
\hline 16 & & $\mathrm{CO}_{2} \mathrm{Bu}^{t}$ & 4.1 \\
\hline
\end{tabular}

${ }^{a} \mathrm{hKir7.1}$ IC50 reported as average from our Thallium flux assay, $\mathrm{n}=3$ 


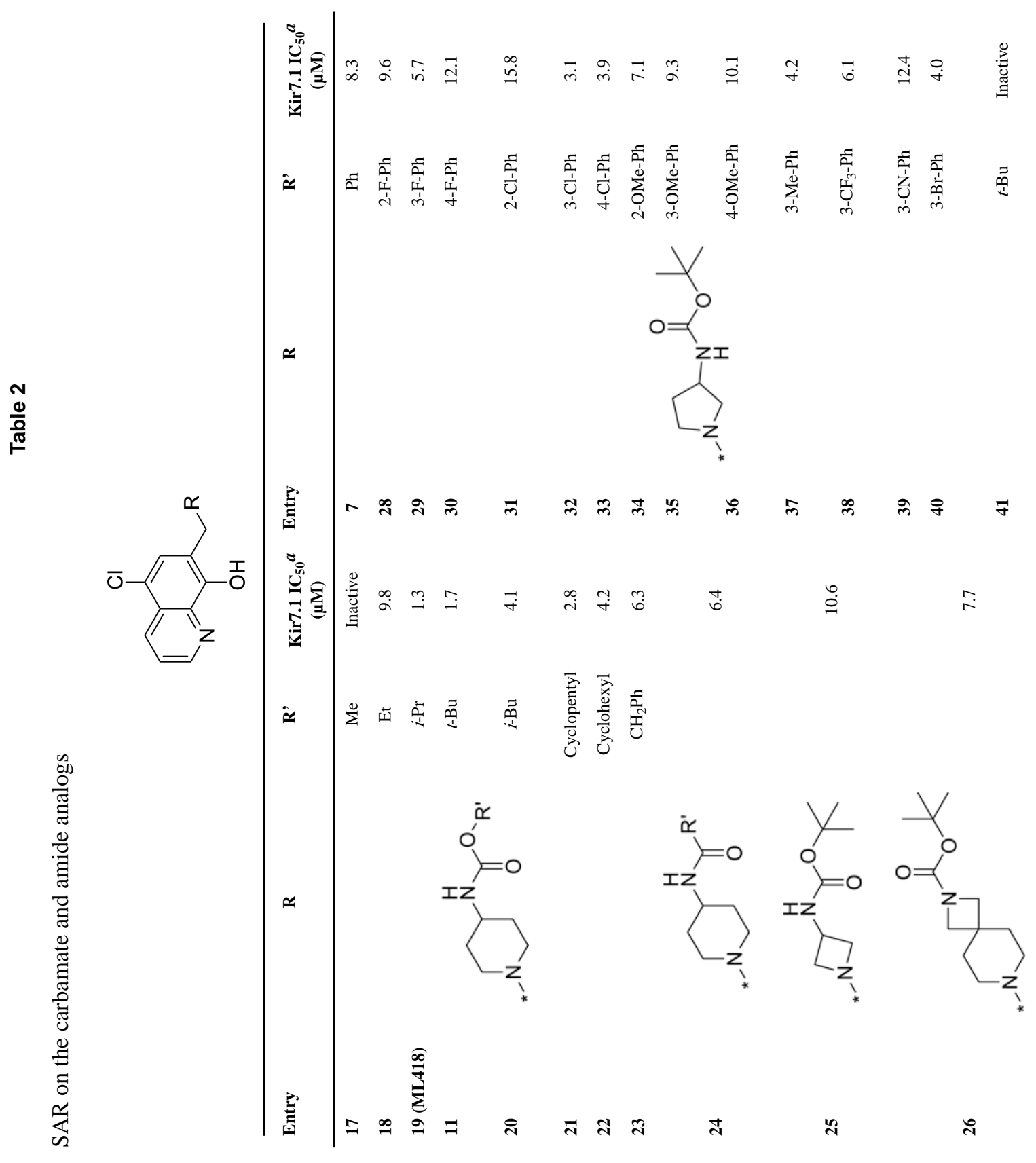

ACS Chem Neurosci. Author manuscript; available in PMC 2016 December 01. 


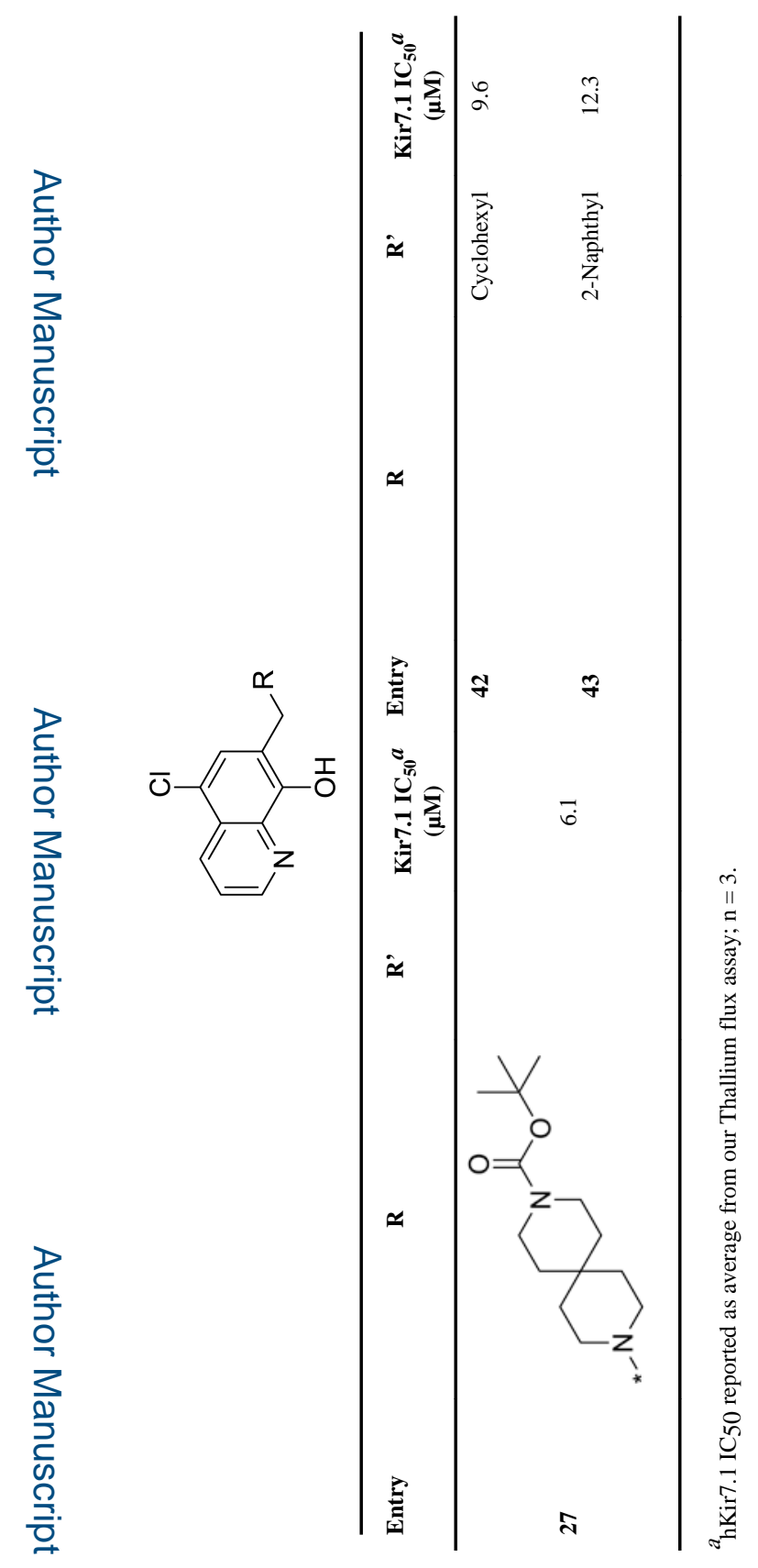

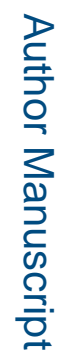

ACS Chem Neurosci. Author manuscript; available in PMC 2016 December 01. 


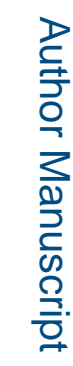

वृ.

$\dot{\mathrm{z}}$

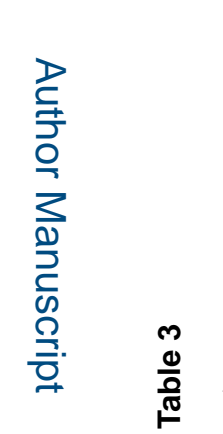

.

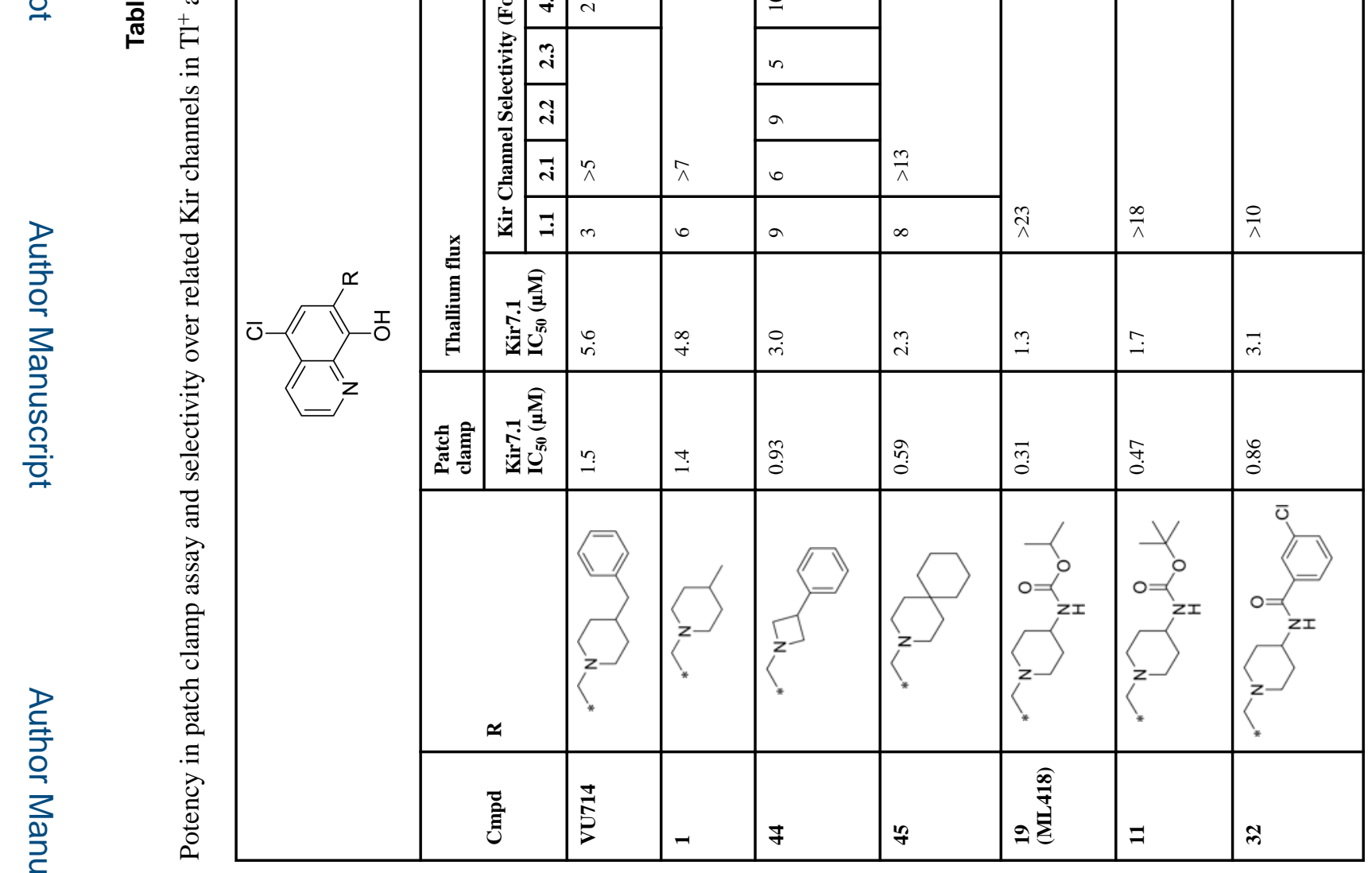

ACS Chem Neurosci. Author manuscript; available in PMC 2016 December 01. 


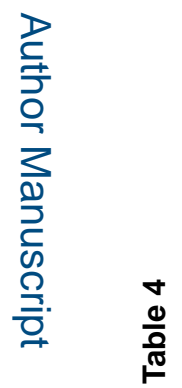

롤

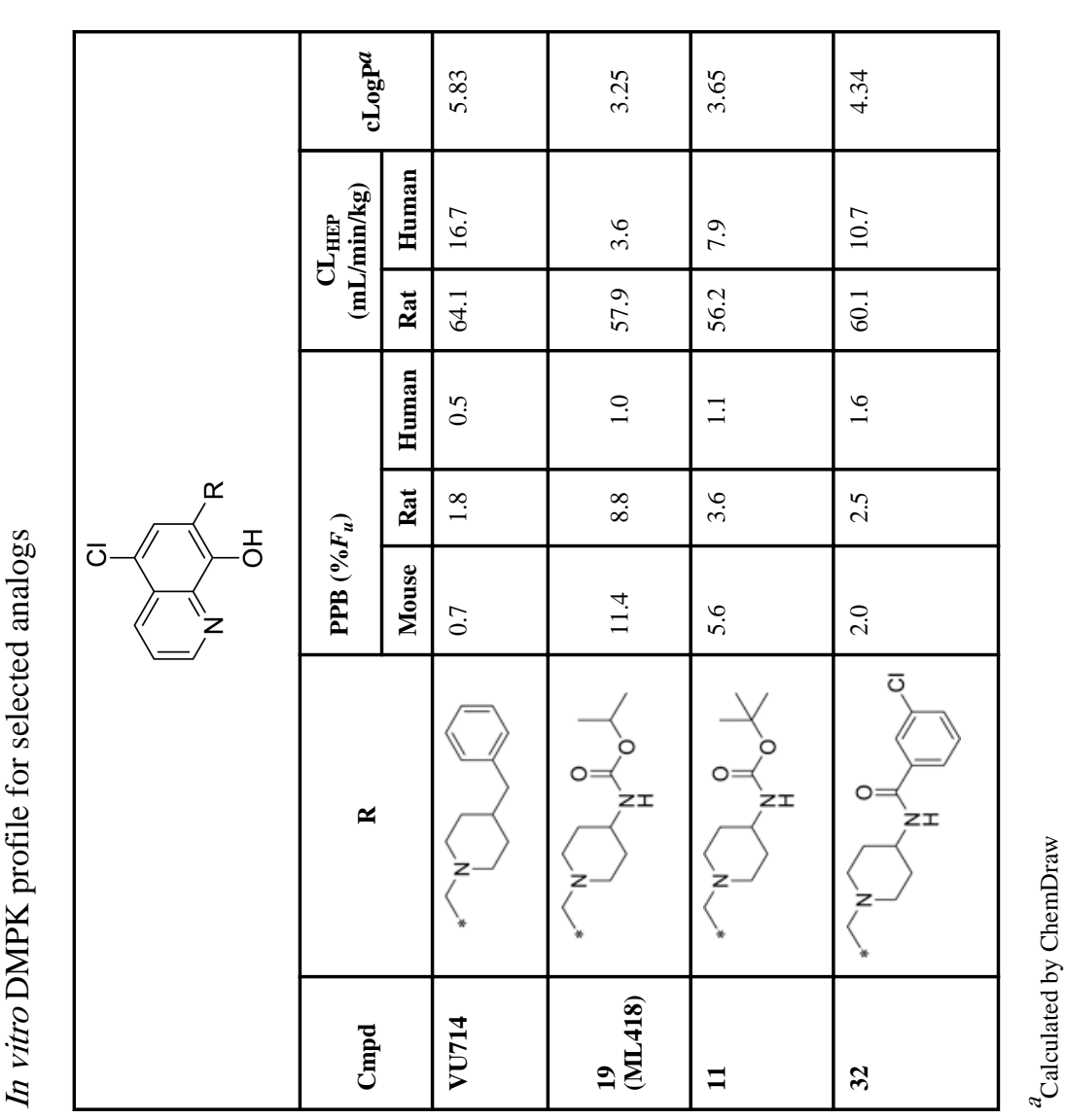

ACS Chem Neurosci. Author manuscript; available in PMC 2016 December 01. 


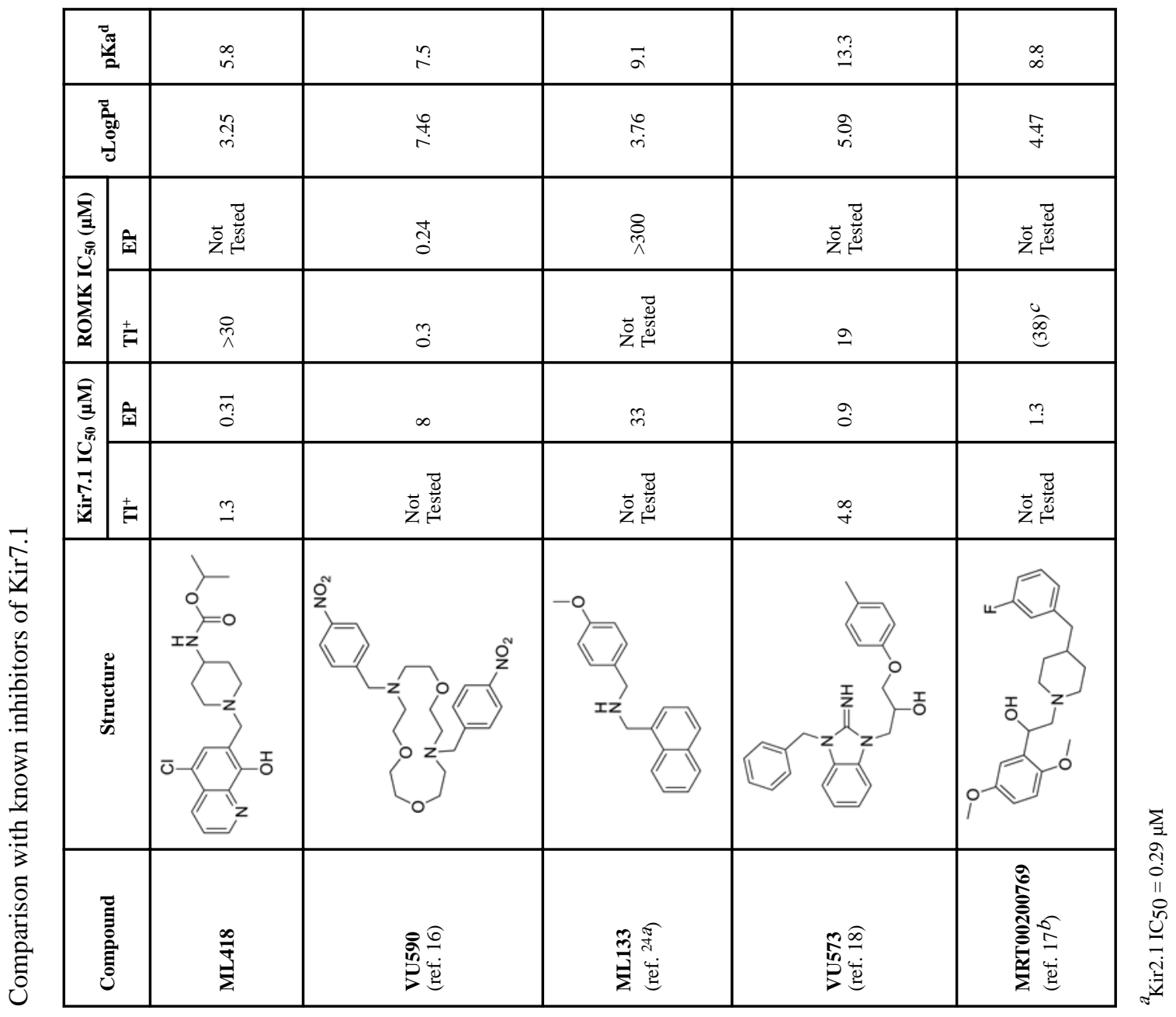

ACS Chem Neurosci. Author manuscript; available in PMC 2016 December 01. 

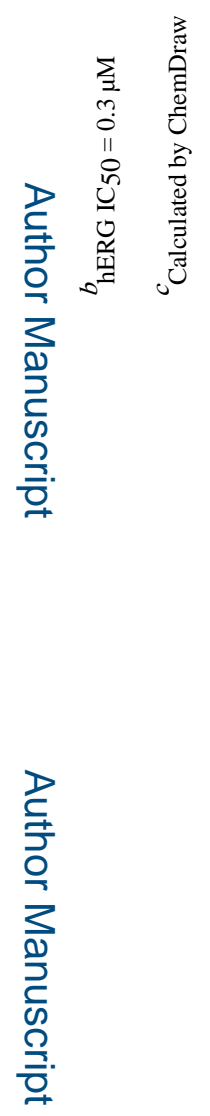

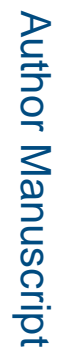

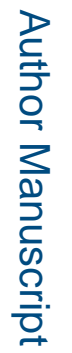

ACS Chem Neurosci. Author manuscript; available in PMC 2016 December 01. 